\title{
The Panjange nigrifrons group in Borneo (Araneae: Pholcidae): high diversity in Sarawak, apparent absence in Sabah
}

\author{
Bernhard A. HUBER ${ }^{1, *}$ \& Charles LEH MOI UNG ${ }^{2}$ \\ ${ }^{1}$ Alexander Koenig Research Museum of Zoology, Adenauerallee 160, 53113 Bonn, Germany. \\ ${ }^{2}$ Sarawak Museum, Jalan Tun Abang Haji Openg, 93566 Kuching, Sarawak, Malaysia. \\ *Corresponding author: b.huber@zfmk.de \\ ²harllmu@sarawak.gov.my \\ ${ }^{1}$ urn:lsid:zoobank.org:author:33607F65-19BF-4DC9-94FD-4BB88CED455F \\ 2 urn:1sid:zoobank.org:author:BF48A807-815E-41E4-BCC6-F3A3FAEDBC9E
}

\begin{abstract}
We revise the Panjange nigrifrons group in Borneo and document an unexpected diversity in western Sarawak forests. Five species occur within $80 \mathrm{~km}$ from Kuching, each species being known from its type locality only. Further species occur east until Niah, but the genus seems to be absent from Sabah. We contrast this with another pholcid genus (Aetana Huber, 2005), which is diverse in Sabah and westward until Niah, but does not seem to occur in central and western Sarawak. Five species are newly described: Panjange kapit Huber, sp. nov., Panjange kubah Huber, sp. nov., Panjange niah Huber, sp. nov., Panjange pueh Huber, sp. nov., Panjange seowi Huber, sp. nov.; Panjange tahai (Huber, 2011) comb. nov. is transferred from Pholcus.
\end{abstract}

Keywords. Sarawak, Sabah, Panjange, taxonomy, biogeography.

Huber B.A. \& Leh Moi Ung C. 2016. The Panjange nigrifrons group in Borneo (Araneae: Pholcidae): high diversity in Sarawak, apparent absence in Sabah. European Journal of Taxonomy 184: 1-32. http://dx.doi.org/10.5852/ ejt.2016.184

\section{Introduction}

In tropical forests around the world, pholcid spiders occupy a variety of microhabitats such as leaf litter, spaces among rocks, logs, and tree buttresses, and green leaves among the vegetation (Huber 2000, 2005). Leaf-dwelling species either attach the apex of their domed web to the underside of a leaf or else spin a barely visible sheet of silk restricted to the (lower) surface of the leaf (Huber 2009; Huber \& Schütte 2009; Huber et al. 2013). In Southeast Asia, leaf-dwelling pholcids are particularly diverse, with some genera consisting entirely of leaf-dwellers (e.g., Calapnita Simon, 1892; Leptopholcus Simon, 1893; Panjange Deeleman-Reinhold \& Deeleman, 1983) and others including leaf-dwellers and representatives in other microhabitats (e.g., Belisana Thorell, 1898; Pholcus Walckenaer, 1805) (Deeleman-Reinhold 1986a, 1986b; Huber 2005, 2011). Some of them exhibit unique morphological or behavioral features, such as eye stalks, extreme elongation of certain body parts, asymmetric genitalia, or 
highly regular webs consisting of sticky and non-sticky lines in analogy to orbicularian webs (DeelemanReinhold 1986a, 1986b; Huber 2005, 2011; Huber \& Nuñeza 2015).

Unfortunately, little is known about the relationships among leaf-dwellers and between leaf-dwellers and their closest relatives in other microhabitats. In only a few cases, phylogenetic analyses of morphological and molecular data have provided a basis for reconstructing the direction of evolutionary shifts among microhabitats. For example, the leaf-dwelling African Smeringopus cylingrogaster (Simon, 1907) and a clade of four Hispaniolan leaf-dwelling species in the genus Modisimus Simon, 1893 are quite clearly derived from near-ground dwelling ancestors (Huber et al. 2010; Huber 2012; Dimitrov et al. 2013); on the other hand, litter-dwelling Metagonia Simon, 1893 species in Brazil and the African litter-dwelling Pholcus kribi Huber, 2011 are apparently derived from leaf-dwelling ancestors (Dimitrov et al. 2013). For Southeast Asian taxa, molecular data have barely been available, and previous efforts at resolving phylogenetic relationships using morphology have often failed to convincingly resolve the relevant nodes (Huber 2011; Huber \& Nuñeza 2015).

The present paper focuses on taxonomy, but is part of a major effort to resolve relationships among Southeast Asian pholcids and to reconstruct their evolutionary histories. It deals with Panjange, a genus that consists of leaf-dwelling species only, but whose internal and external relationships are far from clear. Bornean representatives of Panjange (i.e., representatives of the Panjange nigrifrons group) are in fact more similar to species currently placed in Pholcus from Sumatra, the Malay Peninsula, and Sri Lanka than to other species groups of Panjange in the Philippines (including the type species) and east of the Wallace Line (Huber 2011; Huber \& Nuñeza 2015). It is not yet clear if these similarities are just plesiomorphies or if they reflect the non-monophyly of Panjange. Preliminary molecular data suggest the latter (A. Valdez-Mondragón, D. Dimitrov, B.A. Huber, unpubl. data). In this contribution we will deal with the taxonomy of the Panjange nigrifrons group, we provide basic microhabitat data, and we document a biogeographic peculiarity that has been known in other groups such as birds (e.g., Gawin et al. 2014; Sheldon et al. 2015) but to our knowledge not in spiders: an apparent distributional limit between Sarawak and Sabah.

\section{Material and methods}

Most of the material studied herein was collected during a recent expedition to northern Borneo (JulyAugust 2014). The material is currently deposited at Sarawak Museum, Kuching (SMK), Malaysia and Zoologisches Forschungsmuseum Alexander Koenig, Bonn (ZFMK), Germany. Additional material came from the American Museum of Natural History, New York (AMNH), U.S.A. and the Netherlands Centre for Biodiversity Naturalis, Leiden (RMNH), the Netherlands.

Species descriptions are arranged as in the cladogram in Huber \& Nuñeza (2015). Methods and terminology used are as in recent revisions (Huber 2011, 2013). Measurements are in mm unless otherwise specified. Eye measurements are $\pm 5 \mu \mathrm{m}$. Epigyna were cleared in warm $\mathrm{NaOH}$ solution and stained with chlorazol black. For SEM photos, specimens were dried in HMDS (Brown 1993) and photographed with a Hitachi S-2460 scanning electron microscope. SEM data are presented within the descriptions but are not based on the holotype specimens described. Locality coordinates are in round brackets when copied from labels and original publications or when received directly from collectors, in square brackets when originating from some other source (such as online gazetteers, Google Earth, etc.). The distribution maps were generated with ArcMap 10.0.

The following abbreviations are used in the text:

ALE $=$ anterior lateral eyes

ALS $=$ anterior lateral spinnerets

$\mathrm{AME}=$ anterior median eyes 
a.s.l. = above sea level

$\mathrm{L} / \mathrm{d}=$ length/diameter

$\mathrm{PME}=$ posterior median eyes

In order to avoid confusion, Panjange is abbreviated as "Pa." while Pholcus is never abbreviated. Further abbreviations used only in figures are explained directly in the figure legends.

\section{Results}

Class Arachnida Cuvier, 1812

Order Araneae Clerck, 1757

Family Pholcidae C.L. Koch, 1851

Genus Panjange Deeleman-Reinhold \& Deeleman, 1983

Panjange Deeleman-Reinhold \& Deeleman, 1983: 123-124. Type species by original designation: Panjange lanthana Deeleman-Reinhold \& Deeleman, 1983.

Panjange-Deeleman-Reinhold 1986a: 47, fig. 6; 1986b: 220. — Huber 2001: 118-119; 2011: 108-110. - Huber \& Nuñeza 2015: 3-8.

\section{Note on species groups}

Previous work on Panjange has identified three species groups, the nigrifrons group on Borneo (Fig. 1), the lanthana group on the Philippines, and the widespread cavicola group (Sulawesi to northern Australia) (Deeleman-Reinhold \& Platnick 1986; Huber 2011; Huber \& Nuñeza 2015). From here on, we will deal only with the nigrifrons group. A separate paper on the lanthana group has recently been published (Huber \& Nuñeza 2015), and a molecular phylogeny of the entire genus and its closest relatives is in preparation (A. Valdez-Mondragón, D. Dimitrov, B.A. Huber, unpubl. data).

\section{Panjange nigrifrons group}

\section{Diagnosis}

Within Panjange, males of the nigrifrons group are easily distinguished from other species groups (lanthana and cavicola groups) by presence of distal cheliceral apophyses (arrow in Fig. 18) and by ventral apophysis on palpal femur (arrow in Fig. 30); also by absence of long elongation of palpal tarsus (convergently also in some species of lanthana group) and - females - by absent or very short scape (relatively long in $\mathrm{Pa}$. nigrifrons and $\mathrm{Pa}$. kapit sp. nov.). From representatives of the very similar Pholcus minang group by ridges ventrally on procursus (Figs 17, 26, 34, 49; absent in Pa. tahai comb. nov.), by ventral apophysis on palpal femur, and possibly by wide opening of tarsal organ (figs 481 and 686 in Huber 2011). From other similar genera on Borneo (Pholcus group of genera sensu Huber 2011: Calapnita Simon, 1892; Leptopholcus Simon, 1893; Pholcus Walckenaer, 1805; Uthina Simon, 1893 ) by combination of male coloration (e.g., Figs 8, 61; male ocular area and palps black; similar only in some Pholcus), by bipartite distal apophyses on male chelicerae (Figs 35, 47; similar only in some Calapnita), by cylindrical rather than worm-shaped abdomen (Figs 8-15, 61-68; in contrast to Calapnita and Leptopholcus).

\section{Description}

Male

MeAsurements. Total body length $\sim 4-5$; carapace width $0.9-1.2$; leg 1 length $\sim 35-50$; tibia 1 length 9-12; tibia 2/tibia 4 length 1.05-1.15; tibia $1 \mathrm{~L} / \mathrm{d} \sim 95-115$. 
CoLor. In life (Figs 8, 10-11, 61, 63-66) mostly pale ochre-yellow to whitish with distinctively black ocular area and palps; sternum whitish; legs with dark patellae and tibia-metatarsus joints; abdomen with darker brown to black marks dorsally and laterally, sometimes slightly reddish-brown.

Body. Carapace without median furrow. Ocular area raised, eye triads on stalks of variable length (Figs 2-7), either with or without pointed processes arising from near PME (Figs 2-7). AME always absent, but sometimes with small pigment marks in AME area. Clypeus unmodified. Abdomen cylindrical, slightly angular above spinnerets (Figs 10, 64). Male gonopore with four epiandrous spigots (Fig. 27); each ALS with large widened spigot, pointed spigot, and six cylindrically-shaped spigots (of varying sizes; Figs 28, 44); PMS with two spigots each.

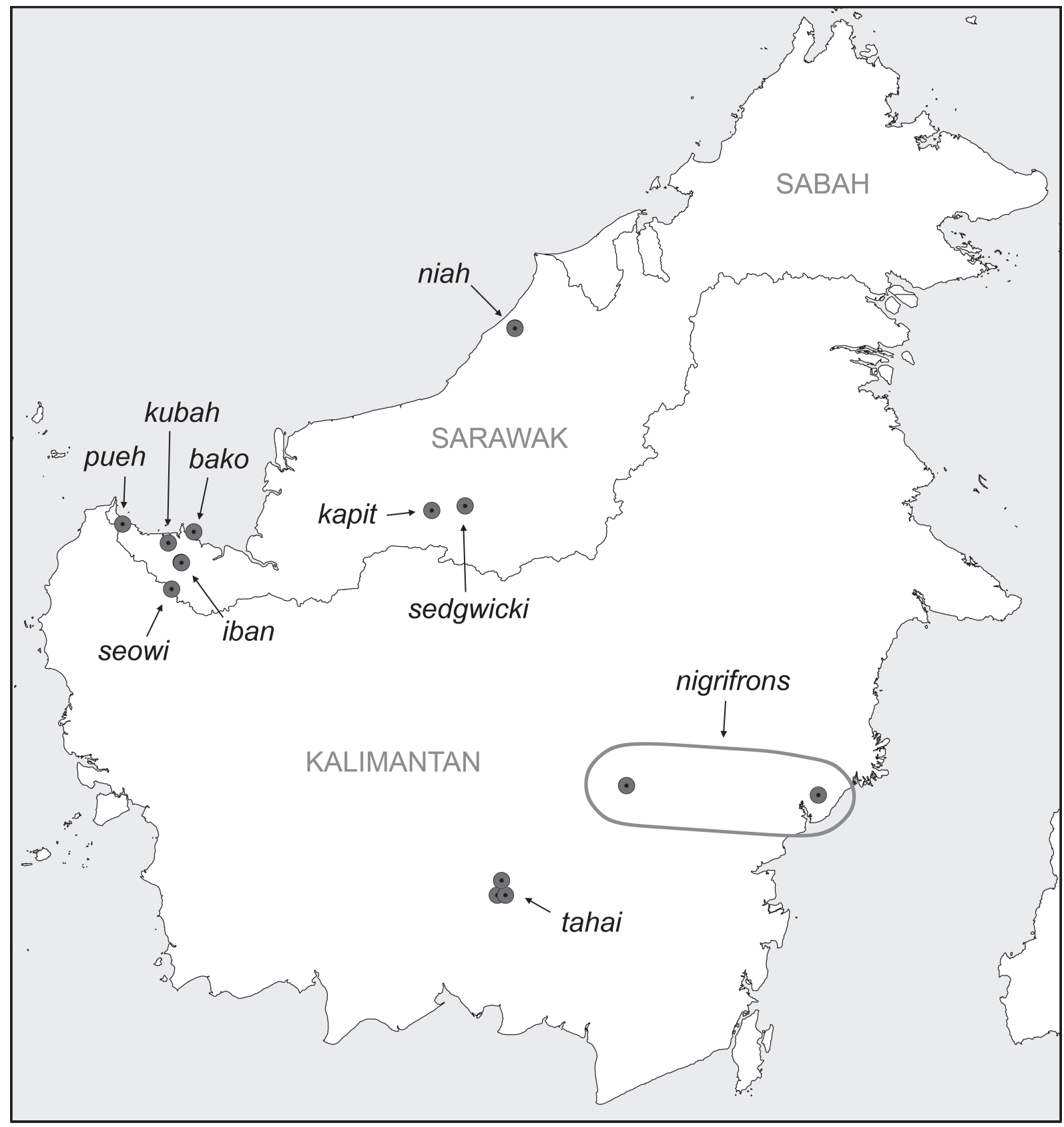

Fig. 1. Known distribution of the Panjange nigrifrons group. 
Chelicerae. With pair of simple proximal lateral processes and distinctively bipartite pair of distal apophyses (Figs 18, 35, 71); without modified hairs; without stridulatory ridges.

PALPS. Coxa unmodified; trochanter with long retrolatero-ventral apophysis (short only in Pa. nigrifrons); femur usually with distinctive finger-shaped ventral apophysis (e.g., Figs 30, 70), only in Pa. pueh sp. nov. with more conical ventral process (Fig. 17); patella triangular in lateral view; tibia with two trichobothria; palpal tarsus sometimes with small dorsal process (e.g., Fig. 70); palpal tarsal organ capsulate with very wide opening (cf. figs 481 and 686 in Huber 2011); procursus relatively complex, only in Pa.tahai comb. nov., with hinge dividing proximal and distal parts; parallel ridges on procursus usually distinct and in high number (e.g., Figs 17, 30, 34, 49), in $P a$. nigrifrons only three ridges, in $P a$. tahai comb. nov. without ridges; procursus sometimes with complex membranous processes (Figs 2123,77-79), in some species with distinctive process in distal pit (Figs 22, 80; see also figs 478 and 683 in Huber 2011); bulb with strong proximal sclerite (e.g., Figs 16, 29, 33), with relatively simple appendix and weakly sclerotized embolus; embolus with subterminal fringes or processes (Figs 24-25, 51, 75).

LEGS. Without spines, without curved hairs, few vertical hairs; retrolateral trichobothrium very proximal (tibia 1: at $1.5-3 \%$ of tibia length), prolateral trichobothrium absent on tibia 1, present on other tibiae. Tarsus 1 with $\sim 30-40$ pseudosegments, very indistinct except distally. Tarsus 4 with single row of ventral comb-hairs of Pholcus-type (cf. Huber \& Fleckenstein 2008) (Fig. 45).

\section{Female}

Similar to male but without eye stalks; eye triads on low humps and never with pointed processes (Fig. 38); chelicerae unmodified; legs slightly shorter than in male. Epigynum weakly sclerotized, with distinct 'knob'; either without scape (Fig. 19), with very short scape (Figs 31, 72, 84), or with medium to long scape (Figs 36, 87). Internal genitalia with pair of pore plates of variable shape, sometimes with very complex system of internal folds of unknown function (Figs 59, 90, 93).

\section{Monophyly and relationships}

The cladistic analysis in Huber \& Nuñeza (2015) included all available species of Panjange except for $P a$. tahai comb. nov. It resolved the Pa. nigrifrons group as monophyletic, but with weak support (only one synapomorphy: the ventral apophysis on the male palpal femur). Internal relationships and relationships to other species groups in Panjange and to Pholcus also remained unconvincing. Preliminary molecular data (including six species of the $P a$. nigrifrons group and six species of the $P a$. lanthana group; A. Valdez-Mondragón, D. Dimitrov, B.A. Huber, unpubl. data) suggest that Panjange is not monophyletic and that the $P a$. nigrifrons group is in fact more closely related to species currently in Pholcus than to the Pa. lanthana group. Morphological data partly point in the same direction (e.g., the bipartite cheliceral apophyses that occur in the Pa.nigrifrons group as well as in the Pholcus minang group) but problems arise from character conflict, dubious homologies of bulbal sclerites, and missing SEM data for many species (especially of the potentially closely related Pholcus minang group).

Pholcus tahai [now Panjange tahai (Huber, 2011) comb. nov.] from Kalimantan was not included in the cladistic analysis in Huber \& Nuñeza (2015). Depending on how the main bulbal process beside the embolus is coded (as unknown, as uncus, or as appendix) the species is either resolved as sister to Panjange or as member of the Pa. nigrifrons group. Each solution has its problems: the procursus of Panjange tahai comb. nov. partly looks very different from that of representatives of the Pa. nigrifrons group: it lacks ventral ridges and it has a hinge dividing proximal and distal parts; on the other hand, the tip of the procursus (compare fig. 684 in Huber 2011 with Fig. 80 herein) and the shape of the tarsal organ (compare figs 481 and 685 in Huber 2011) remind strongly of other representatives of the $P a$. nigrifrons group. One further hint toward a closer affinity with the $P$ a. nigrifrons group is biogeography: $P a$. tahai comb. nov. occurs on Borneo like all other species of the Pa. nigrifrons group, while all 
species of the Pholcus minang group (to which the species was previously assigned) are from Sumatra and the Malay Peninsula (Huber 2011).

\section{Natural history}

All species observed in the field share a very similar microhabitat and web. They were consistently found in webs among low vegetation in well preserved forests, usually at about $0.5 \mathrm{~m}$ above the ground or even lower. The domed webs had a diameter of about $15-20 \mathrm{~cm}$ and were at their apex connected to the underside of a leaf where the spiders rested. At some localities, large numbers of cecidomyiid flies were found hanging in the webs together with the spiders. Egg-sacs are slightly elongated and contain approximately 20-30 eggs (e.g., Figs 13, 62).

\section{Composition}

As construed here, the Panjange nigrifrons group now includes ten species: Panjange bako Huber, 2011; Pa. iban Huber, 2011; Pa. kapit sp. nov.; Pa. kubah sp. nov.; Pa. niah sp. nov.; Pa. nigrifrons DeelemanReinhold \& Deeleman, 1983; Pa. pueh sp. nov.; Pa. sedgwicki Deeleman-Reinhold \& Platnick, 1986; Pa. seowi sp. nov.; Pa. tahai (Huber, 2011) comb. nov. Judging from known distribution patterns in Sarawak and from the large poorly sampled forests of Kalimantan, the group is likely to contain several times as many species. However, the absence of Panjange in northeastern Borneo may be real rather than an artifact of poor sampling. Our own collecting at nine localities east of Niah did not produce a single specimen of Panjange (Fig. 95; see Discussion).

\section{Distribution}

Known from Borneo only (Fig. 1).

$$
\begin{gathered}
\text { Panjange pueh Huber, sp. nov. } \\
\text { urn:1sid:zoobank.org:act:792671DD-F7D9-4497-BD2B-84E925032C4C }
\end{gathered}
$$

Figs 2, 8-9, 16-28, 52-54

Panjange Bor 96: Huber \& Nuñeza 2015: 5, 43-44.

\section{Diagnosis}

Distinguished from similar species (with pair of pointed processes arising from near PME and ventral apophysis on male palpal femur: Pa. bako; Pa. kapit sp. nov.; Pa. niah sp. nov.; Pa. sedgwicki; Pa. tahai comb. nov.) by details of male pedipalp (Figs 16-17; simple conical ventral femur apophysis; distinctive prolateral membranous process on procursus; shape of procursus tip; short appendix, similar only in $P a$. niah sp. nov.); from Pa. kapit sp. nov. also by shorter palpal segments and shorter epigynal scape (Figs 17, 19). Females are difficult to distinguish from $P a$. bako and $P a$. niah sp. nov. (internal transversal folds much more complex in $P a$. bako, very similar in $P a$. niah sp. nov.; unknown in $P a$. sedgwicki).

\section{Etymology}

Named for the type locality; noun in apposition.

\section{Type material}

MALAYSIA-BORNEO: holotype, ô, Sarawak, Pueh foothills, forest along river $\left(1.798-1.800^{\circ} \mathrm{N}\right.$, 109.708-109.718 E), 100-200 m a.s.1., 16 Jul. 2014 (B.A. Huber, S.B. Huber), ZFMK (Ar 14575).

\section{Other material examined}

MALAYSIA-BORNEO, Sarawak: 3 $\widehat{\jmath}, 5$ 우, same data as holotype, ZFMK (Ar 14576-77); 1 q, 3 juvs, in absolute ethanol, same data, ZFMK (Bor 231). 


\section{Description}

Male (holotype)

Measurements. Total body length 5.0, carapace width 1.1. Leg 1: $44.3(9.9+0.5+10.2+21.1+2.6)$, tibia 2: 6.3, tibia 3: 3.5, tibia 4: 5.8; tibia $1 \mathrm{~L} / \mathrm{d}$ : 106. Distance PME-PME $490 \mu \mathrm{m}$, diameter PME $105 \mu \mathrm{m}$, distance PME-ALE $45 \mu \mathrm{m}$; AME absent.

CoLor. Carapace pale ochre yellow to whitish, posterior mark (Fig. 8) lost in ethanol, ocular area and clypeus dark brown (black in life); sternum whitish; legs ochre-orange with dark brown patellae and tibia-metatarsus joints; abdomen ochre-gray, with black marks dorsally, monochromous ventrally.

Body. Habitus as in Fig. 8; ocular area raised, each triad on long stalk, with pointed straight process arising from near PME (Figs 2, 18); carapace without median furrow; clypeus unmodified; sternum
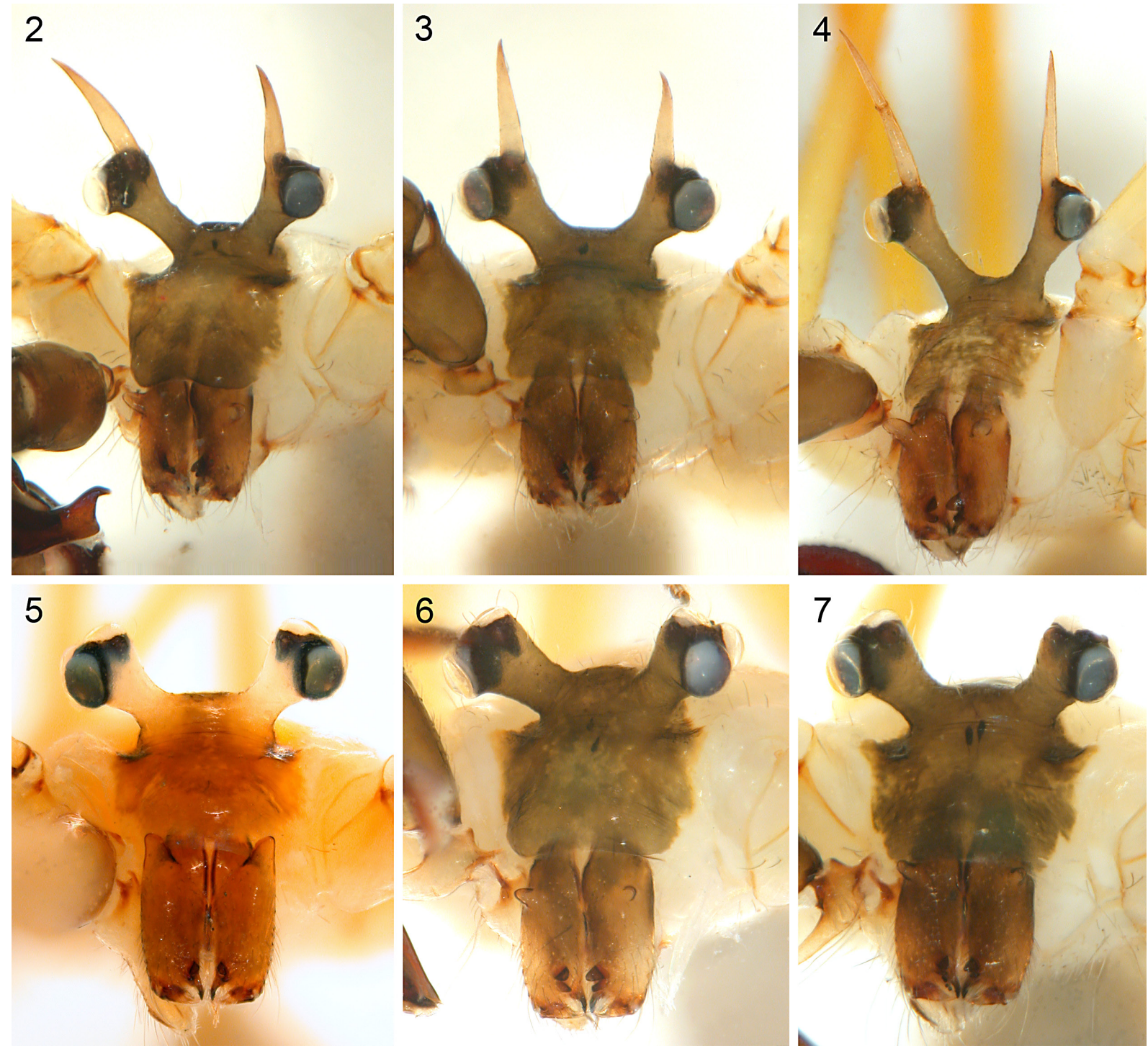

Figs 2-7. Male prosomata, oblique frontal views. 2. Panjange pueh Huber, sp. nov. (ZFMK Ar 14576). 3. Pa. niah Huber, sp. nov. (ZFMK Ar 14579). 4. Pa. kapit Huber, sp. nov. (ZFMK Ar 14583). 5. Pa. nigrifrons Deeleman-Reinhold \& Deeleman, 1983 (RMNH, Sepaku). 6. Pa. kubah Huber, sp. nov. (ZFMK Ar 14587). 7. Pa. seowi Huber, sp. nov. (ZFMK Ar 14590). 
wider than long (0.7/0.6), unmodified. Gonopore with four epiandrous spigots (Fig. 27). ALS as in Fig. 28.

Chelicerae. Similar to close relatives, with proximal pair of processes and with distinctively bipartite distal apophyses (Fig. 18); without modified hairs; without stridulatory ridges.

PALPS. As in Figs 16-17; coxa unmodified; trochanter with slightly curved retrolatero-ventral apophysis and low retrolateral hump; femur with conical ventral process; procursus with row of about 26 ventral ridges (Fig. 26), with distinctive prolateral membranous process and distal elements (Figs 21-23); bulb with strong proximal sclerite, short curved appendix, and proximally widened and sclerotized embolus with distal processes and fringes (Figs 24-26).
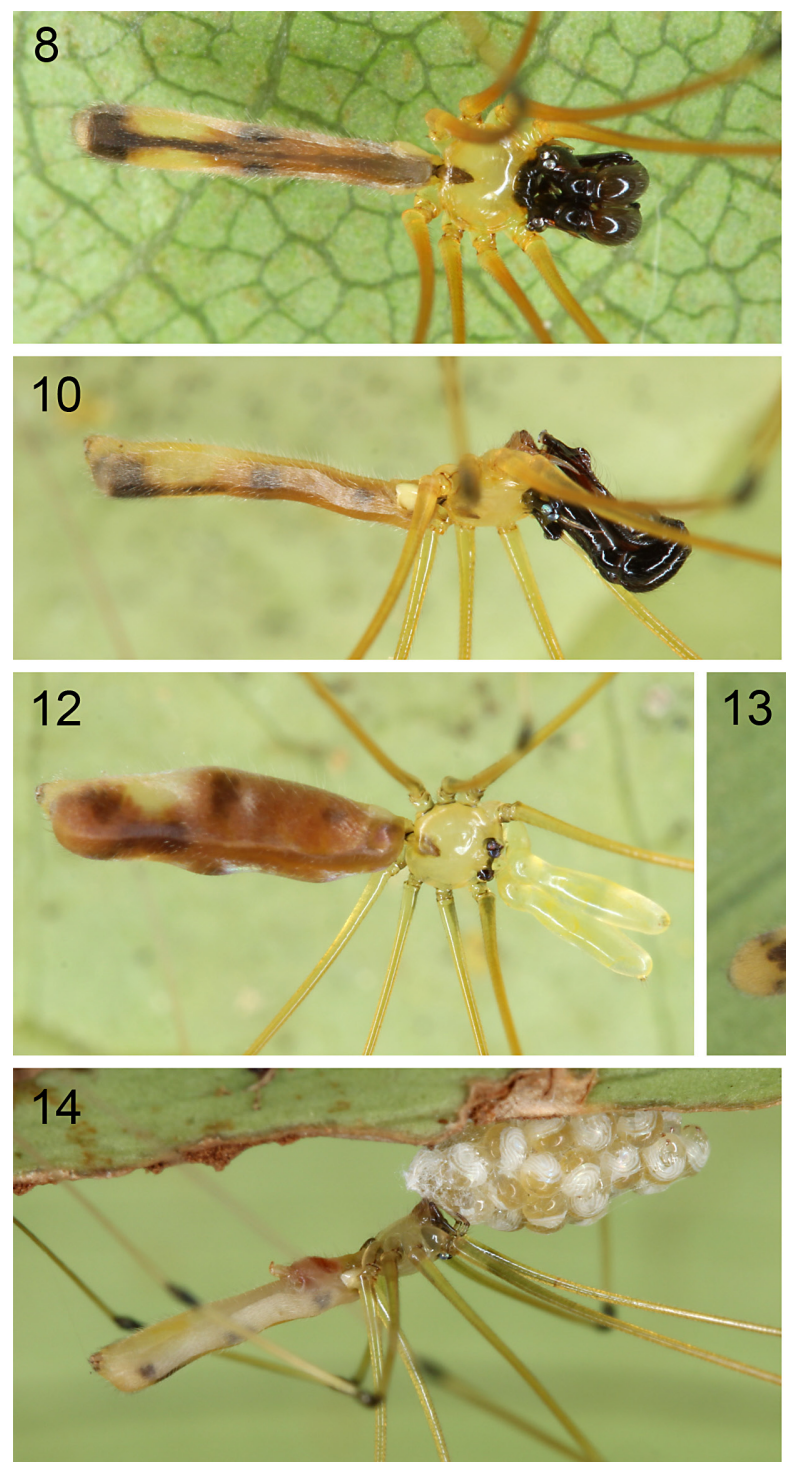
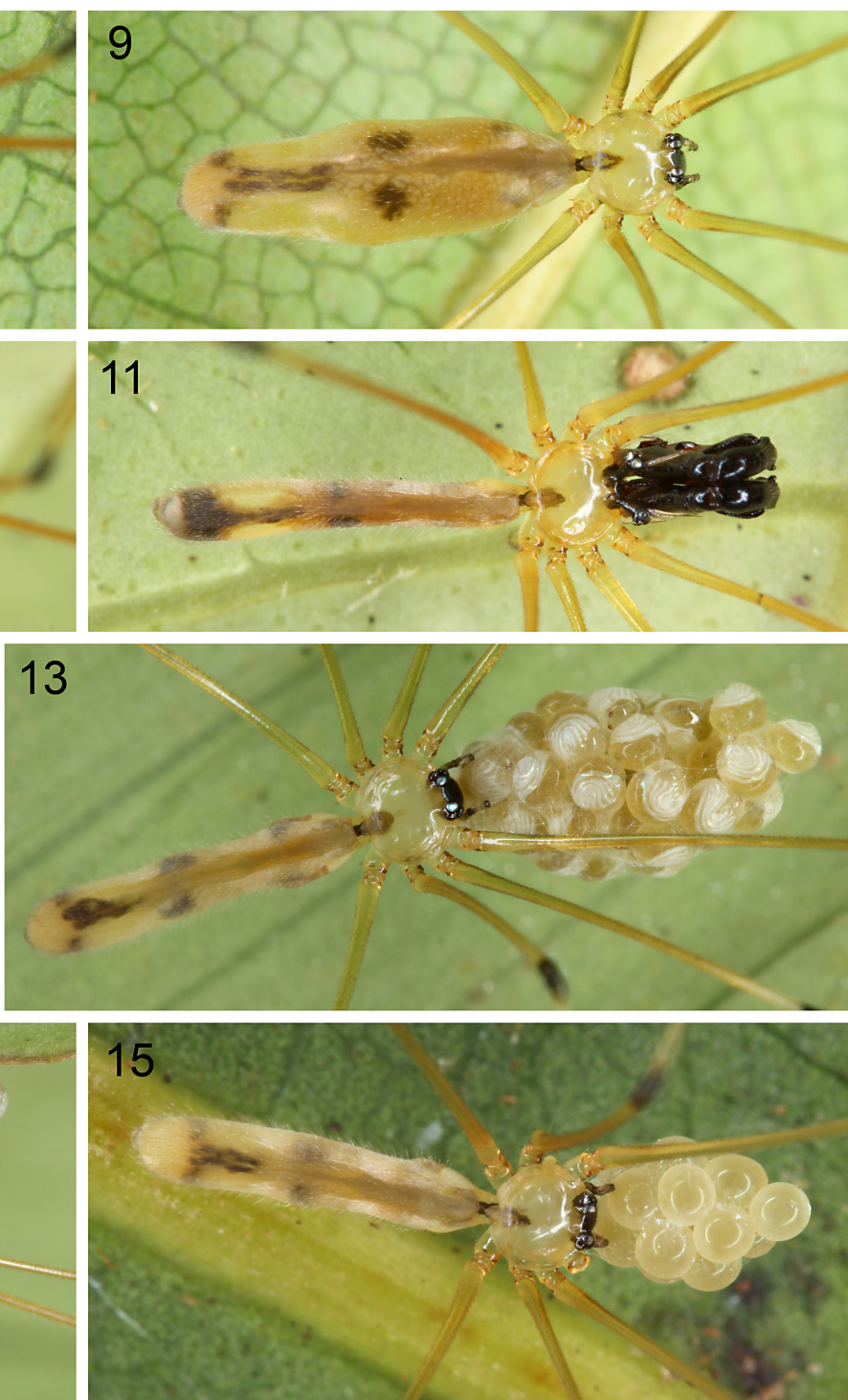

Figs 8-15. Live specimens. 8-9. Panjange pueh Huber, sp. nov., $\overbrace{}^{\Uparrow}$ and $\odot$ from Pueh. 10-14. Pa. kapit Huber, sp. nov. from Kapit. 10-11. Adult $\partial^{\lambda}, 12$. Penultimate instar $\partial^{\lambda}, 13-14$. $q$ with egg-sac. 15. Pa. niah Huber, sp. nov., 9 with egg-sac from Niah. 


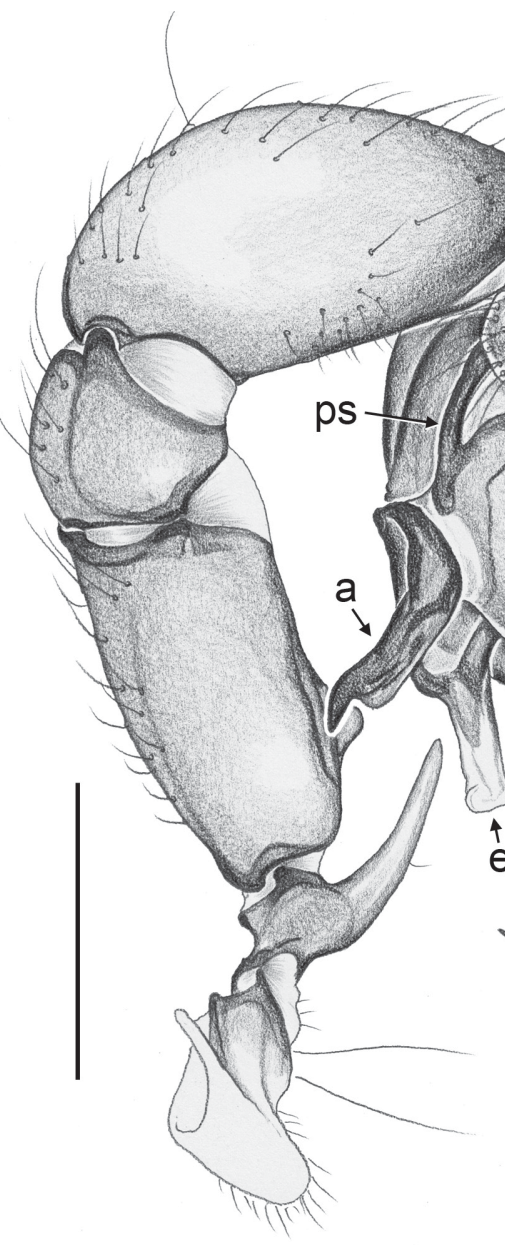

16
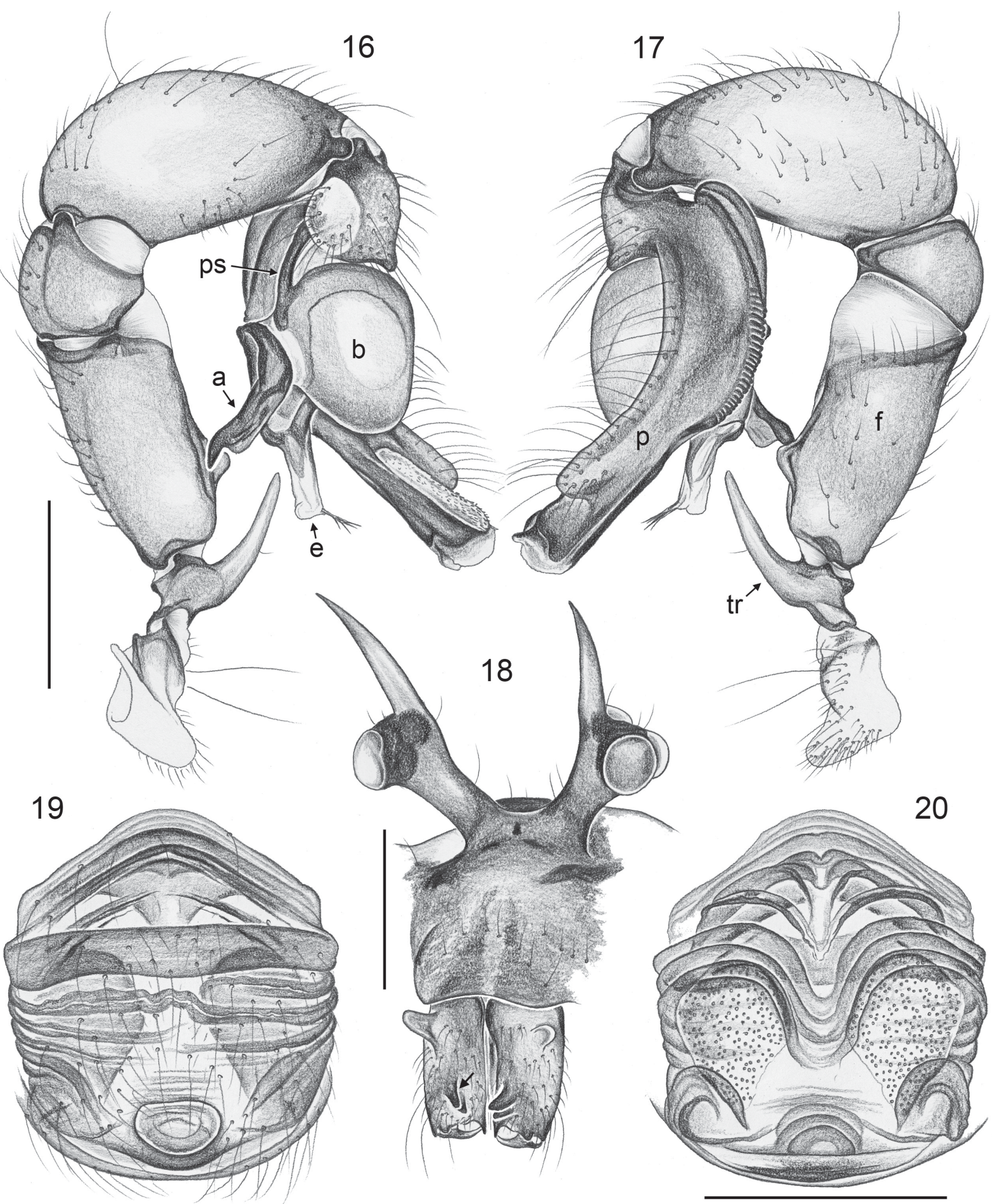

Figs 16-20. Panjange pueh Huber, sp. nov. (ZFMK Ar 14576-77). 16-17. Left male palp, prolateral and retrolateral views. 18. Male ocular area, clypeus, and chelicerae, oblique frontal view (arrow points at distal cheliceral apophysis). 19-20. Cleared female genitalia, ventral and dorsal views. Abbreviations: $\mathrm{a}=$ appendix $; \mathrm{b}=$ genital bulb; $\mathrm{e}=$ embolus; $\mathrm{f}=$ femur; $\mathrm{p}=$ procursus; $\mathrm{ps}=$ proximal bulbal sclerite $\mathrm{tr}=$ trochanter. Scale lines: $0.5 \mathrm{~mm}$. 

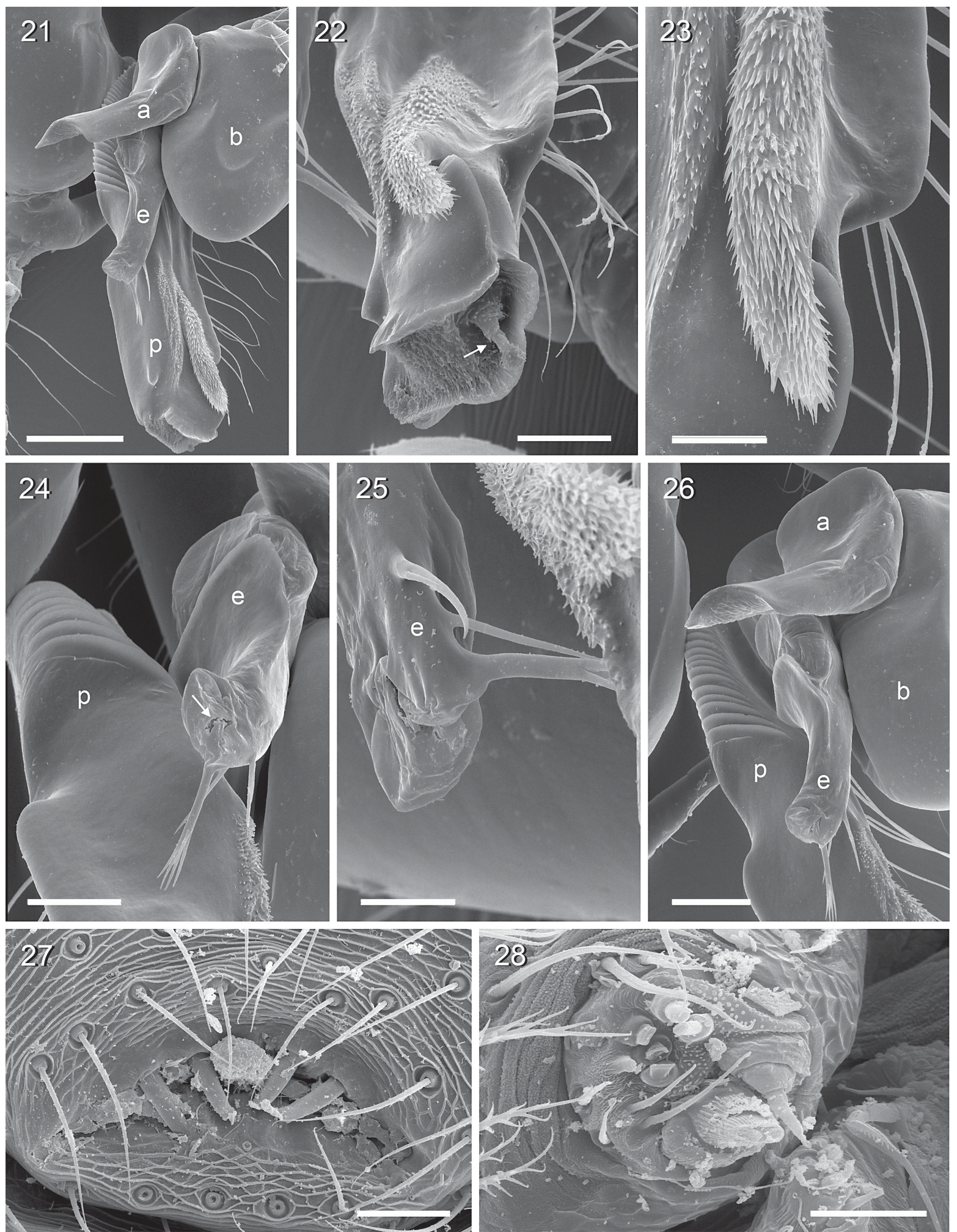

Figs 21-28. Panjange pueh Huber, sp. nov. (ZFMK Ar 14576). 21. Left procursus and bulb, prolateral view. 22. Left procursus, prolateral distal view (arrow points to distinctive process in distal pit). 23. Prolateral membranous process on left procursus. 24-25. Tip of embolus, distal views. 26. Left procursus and bulb, prolatero-distal view. 27. Male gonopore. 28. Male ALS. Abbreviations: a = appendix; $\mathrm{b}=$ genital bulb; $\mathrm{e}=$ embolus; $\mathrm{p}=$ procursus. Scale lines: $20 \mu \mathrm{m}(28) ; 30 \mu \mathrm{m}(25,27) ; 40 \mu \mathrm{m}$ (23); $60 \mu \mathrm{m}(22,24) ; 100 \mu \mathrm{m}(26) ; 200 \mu \mathrm{m}(21)$. 
LEGS. Without spines and curved hairs; few vertical hairs; retrolateral trichobothrium on tibia 1 at $1.5 \%$; prolateral trichobothrium absent on tibia 1 , present on other tibiae; tarsus 1 with $>40$ indistinct pseudosegments.

\section{Variation}

Tibia 1 in 3 other males: 8.9, 9.3, 9.6.

Female

In general similar to male but eye triads on low humps, much closer together (distance PME-PME $235 \mu \mathrm{m}$ ), without pointed processes. Tibia 1 in 5 females: 7.6-8.3 (mean 7.9). Epigynum weakly sclerotized plate with large weakly sclerotized posterior 'knob' (Figs 19, 52), internal arch and transversal folds visible through cuticle; internal genitalia as in Figs 20, 53-54.

\section{Distribution}

Known from type locality in Sarawak only (Fig. 1).

Panjange niah Huber, sp. nov. urn:lsid:zoobank.org:act:BBDABF75-A656-4B28-AA6A-88D20F1CC113

Figs 3, 15, 29-32, 38-41, 55-57

Panjange Bor 11: Huber \& Nuñeza 2015: 5, 43-44.

\section{Diagnosis}

Distinguished from similar species (with pair of straight pointed processes arising from near PME and ventral apophysis on male palpal femur: Pa. bako; Pa. kapit sp. nov.; Pa. pueh sp. nov.; Pa. sedgwicki; $P a$. tahai comb. nov.) by shapes of procursus and appendix (Figs 29-30; procursus tip distinctively bifid, similar only in Pa. bako; appendix short and curved, similar only to Pa. pueh sp. nov.). Females are difficult to distinguish from $P a$. bako and $P a$. pueh sp. nov. (internal transversal folds much more complex in Pa. bako, very similar in $\mathrm{Pa}$. pueh sp. nov.; unknown in $\mathrm{Pa}$. sedgwicki).

\section{Etymology}

Named for the type locality; noun in apposition.

\section{Type material}

MALAYSIA-BORNEO: holotype, ${ }^{\lambda}$, Sarawak, Niah Cave National Park, forest near headquarters $\left(3.820^{\circ} \mathrm{N}, 113.763^{\circ} \mathrm{E}\right), 40 \mathrm{~m}$ a.s.l., night collecting, 28 Jul. 2014 (B.A. Huber, S.B. Huber), ZFMK (Ar $14578)$.

\section{Other material examined}

MALAYSIA-BORNEO, Sarawak: 1 ㄱ, 8 우우, 1 juv., same data as holotype, ZFMK (Ar 14579-80); 2 우옹 same locality, forest along main trail $\left(3.814-3.821^{\circ} \mathrm{N}, 113.763-113.771^{\circ} \mathrm{E}\right), 20-40 \mathrm{~m}$ a.s.1., 27 Jul. 2014 (B.A. Huber, S.B. Huber), ZFMK (Ar 14581); 3 q $q, 1$ juv., same data, in absolute ethanol, ZFMK (Bor 179).

\section{Description}

Male (holotype)

Measurements. Total body length 4.5, carapace width 1.1. Leg 1: $41.2(9.4+0.5+9.5+19.3+2.5)$, tibia 2: 5.7, tibia 3: 3.3, tibia 4: 5.3; tibia $1 \mathrm{~L} / \mathrm{d}: 108$. Distance PME-PME $445 \mu \mathrm{m}$, diameter PME $105 \mu \mathrm{m}$, distance PME-ALE $\sim 5 \mu \mathrm{m}$; AME absent. 

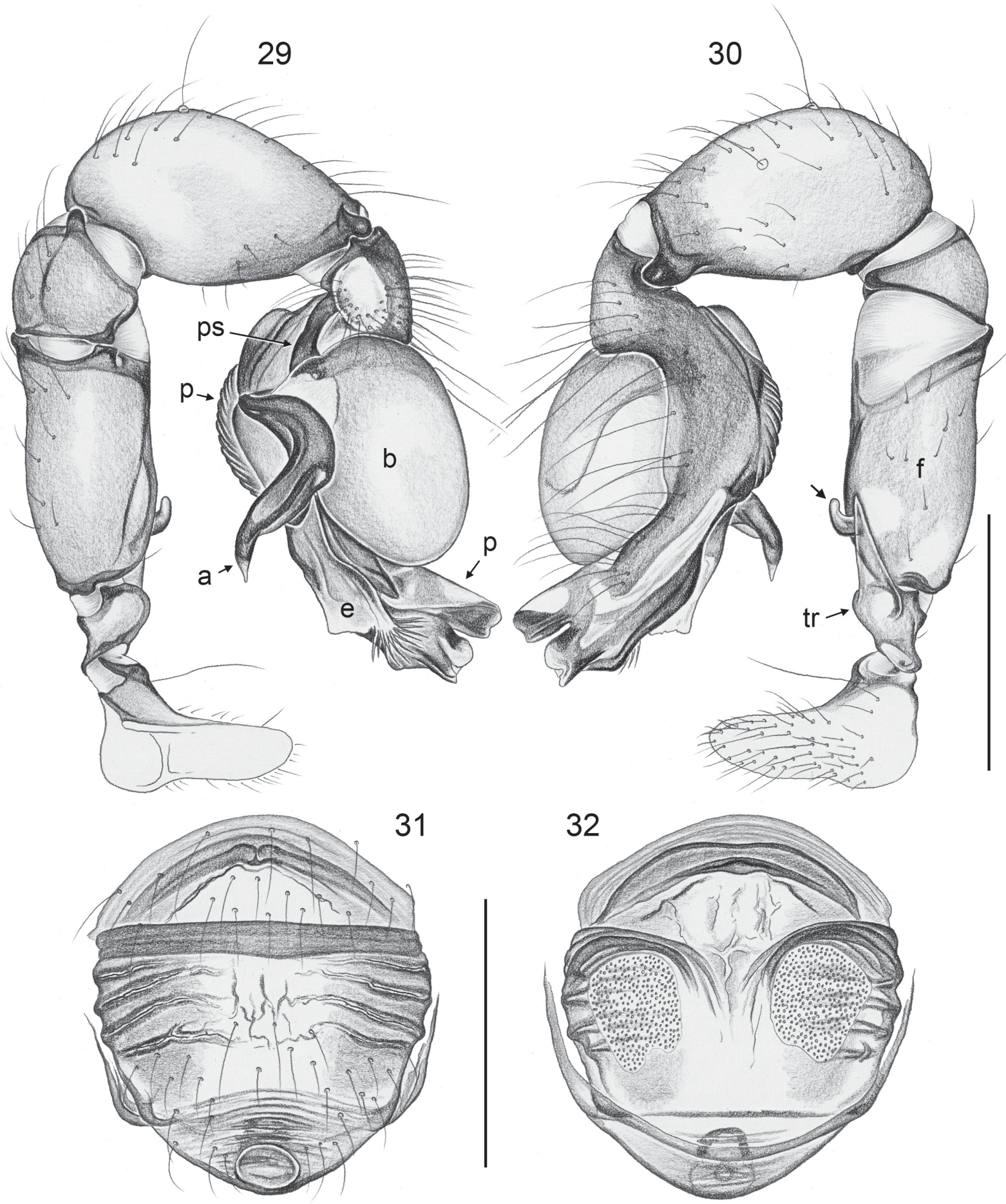

Figs 29-32. Panjange niah Huber, sp. nov. (ZFMK Ar 14579-80). 29-30. Left male palp, prolateral and retrolateral views (arrow points at ventral femur apophysis). 31-32. Cleared female genitalia, ventral and dorsal views. Abbreviations: $\mathrm{a}=$ appendix; $\mathrm{b}=$ genital bulb; $\mathrm{e}=$ embolus; $\mathrm{f}=$ femur; $\mathrm{p}=$ procursus; $\mathrm{ps}=$ proximal bulbal sclerite; $\operatorname{tr}=$ trochanter. Scale lines: $0.5 \mathrm{~mm}$. 
CoLor. Carapace pale ochre yellow to whitish, without posterior mark, ocular area and clypeus dark brown, with single black mark in AME area; sternum whitish; legs ochre-orange with dark brown patellae and tibia-metatarsus joints; abdomen ochre-gray, with black marks dorsally, monochromous ventrally.

Body. Habitus as in $\mathrm{Pa}$. pueh sp. nov. (cf. Fig. 8); ocular area raised, each triad on long stalk, with pointed straight process arising from near PME (Fig. 3); carapace without median furrow; clypeus unmodified; sternum wider than long $(0.70 / 0.55)$, unmodified.

Chelicerae. Similar to Pa. pueh sp. nov. and other close relatives (cf. Fig. 18), with distinctively bipartite distal apophyses; proximal pair of processes slightly directed towards distal; without modified hairs; without stridulatory ridges.
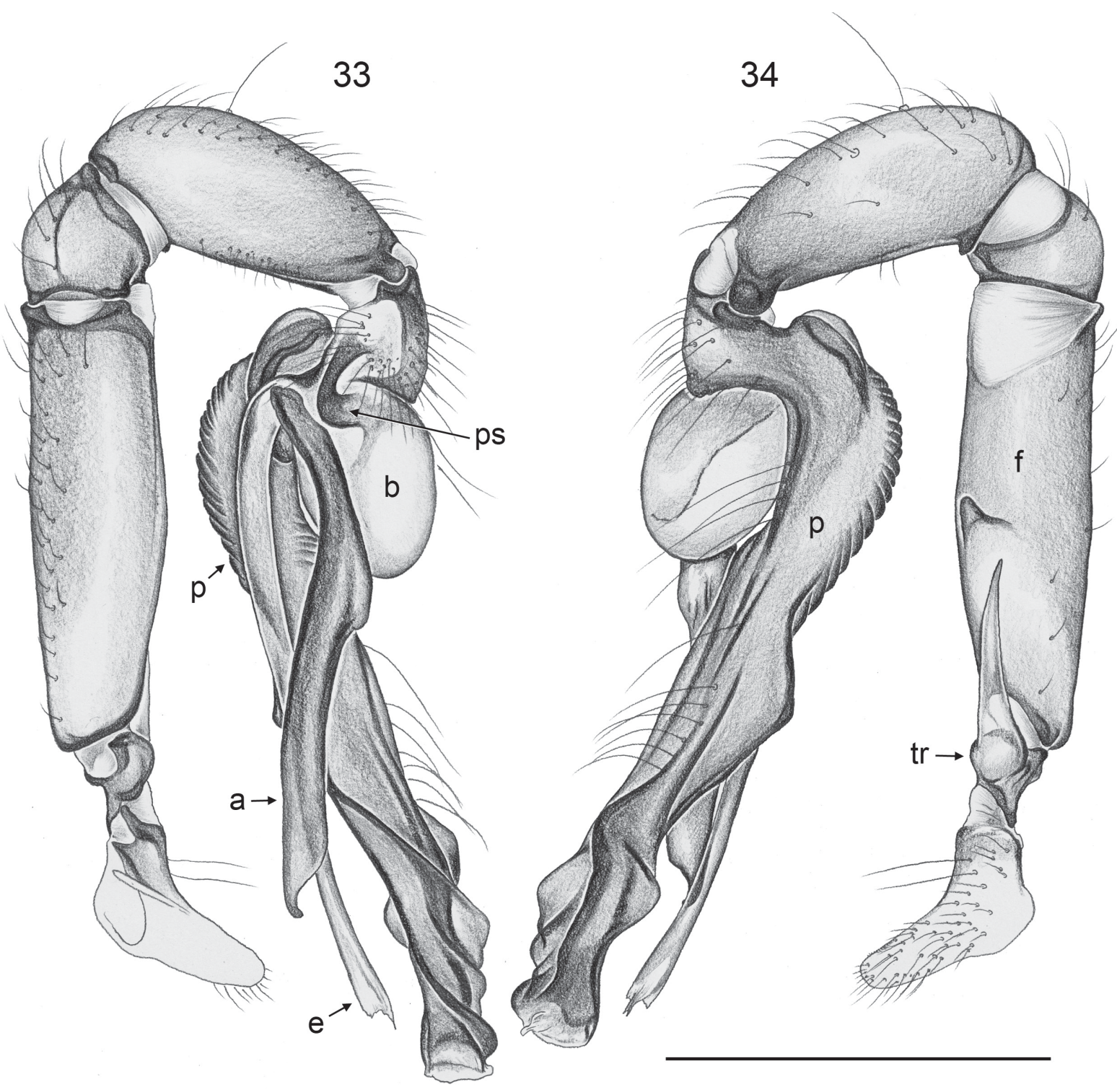

Figs 33-34. Panjange kapit Huber, sp. nov. (ZFMK Ar 14583). Left male palp, prolateral and retrolateral views. Abbreviations: $a=$ appendix; $b=$ genital bulb; $e=$ embolus; $f=$ femur; $p=$ procursus; $p s=$ proximal bulbal sclerite; $\mathrm{tr}=$ trochanter. Scale line: $1 \mathrm{~mm}$. 
PALPS. As in Figs 29-30; coxa unmodified; trochanter with straight pointed retrolatero-ventral apophysis; femur with curved finger-shaped ventral apophysis; procursus with row of about 12 ventral ridges, with distinctive bifid tip; bulb with strong proximal sclerite, strongly curved short appendix, and long partly sclerotized embolus with distinct distal fringes.

Legs. Without spines and curved hairs; few vertical hairs; retrolateral trichobothrium on tibia 1 at $2.5 \%$; prolateral trichobothrium absent on tibia 1 , present on other tibiae; tarsus 1 with $>20$ indistinct pseudosegments.

\section{Variation}

Tibia 1 in other male: 9.0 .

\section{Female}

In general similar to male but eye triads on low humps, much closer together (distance PME-PME $220 \mu \mathrm{m}$ ), without pointed processes. Tibia 1 in 9 females: 6.9-7.5 (mean 7.2). Tarsus 4 comb-hairs as in Figs 39-40. Epigynum weakly sclerotized plate with large posterior 'knob' (Figs 31, 41, 55), internal anterior arch and transversal folds visible through cuticle; internal genitalia as in Figs 32, 56-57.

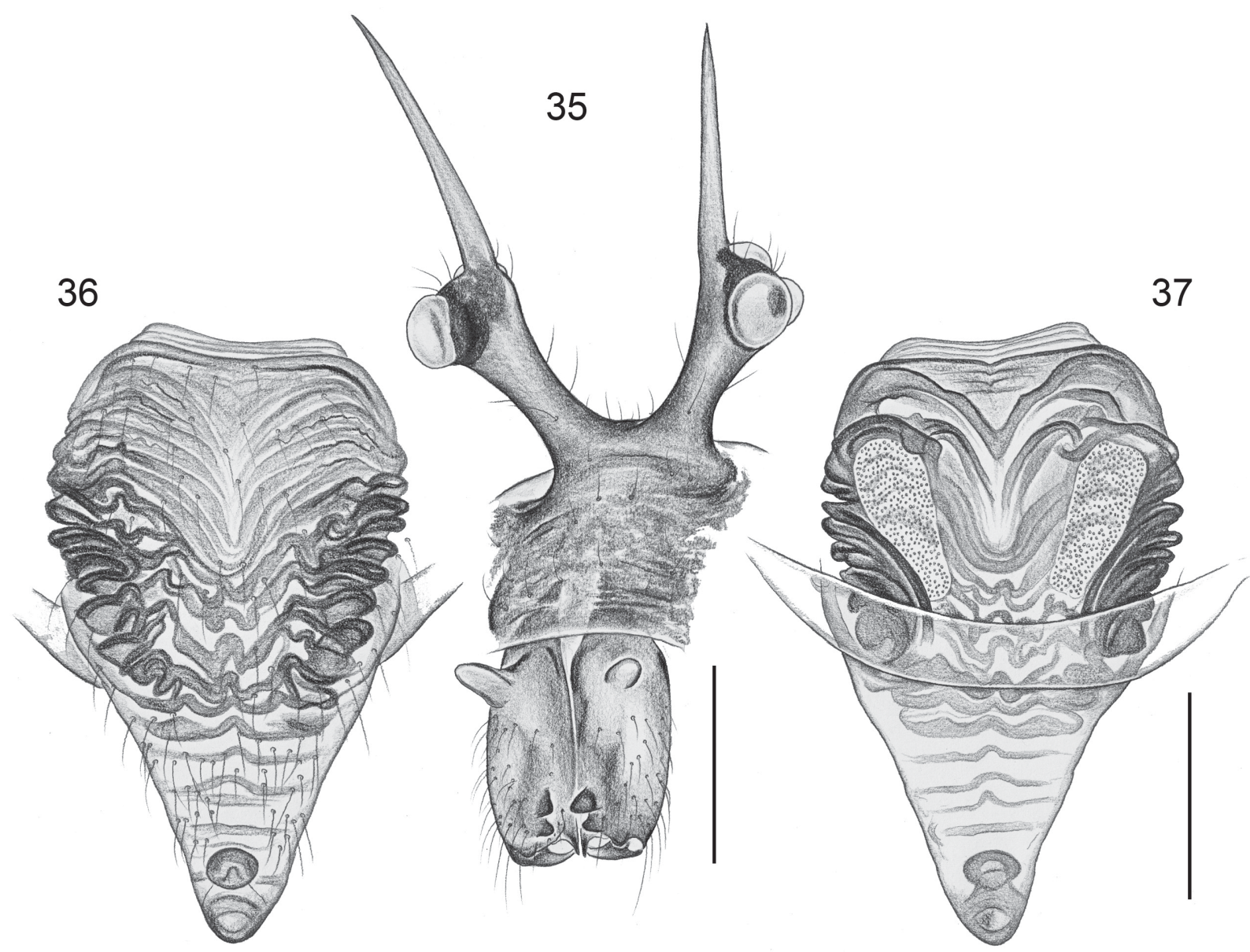

Figs 35-37. Panjange kapit Huber, sp. nov. (ZFMK Ar 14583-84). 35. Male ocular area, clypeus, and chelicerae, oblique frontal view. 36-37. Cleared female genitalia, ventral and dorsal views. Scale lines: $0.5 \mathrm{~mm}$. 

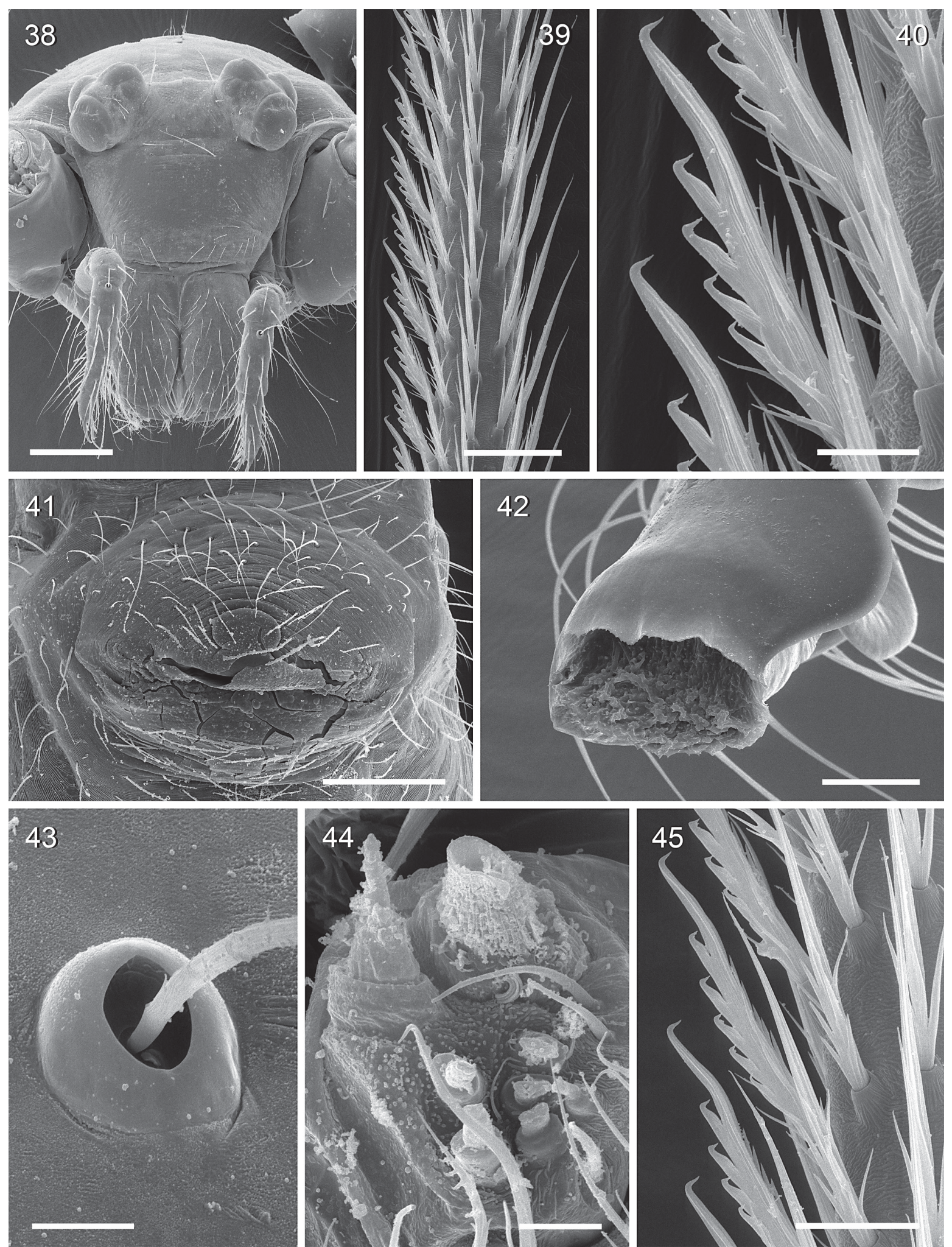

Figs 38-45. - 38-41. Panjange niah Huber, sp. nov. (ZFMK Ar 14580). 38. Female prosoma, frontal view. 39-40. Comb-hairs on female tarsus 4. 41. Epigynum, ventral view. - 42-45. Panjange kapit Huber, sp. nov. (ZFMK Ar 14583). 42. Tip of left procursus, retrolatero-distal view. 43. Base of palpal trichobothrium. 44. Male ALS. 45. Comb-hairs on male tarsus 4. Scale lines: $10 \mu \mathrm{m}$ (40, 43-44); $20 \mu \mathrm{m}$ (45); $40 \mu \mathrm{m}(39) ; 60 \mu \mathrm{m}(42) ; 200 \mu \mathrm{m}(38,41)$. 


\section{Natural history}

The webs were found among the vegetation at $0.5-1 \mathrm{~m}$ above the ground, with the apex of the domed sheet connected to the underside of a leaf.

\section{Distribution}

Known from type locality in Sarawak only (Fig. 1).

\section{Panjange bako Huber, 2011}

Panjange bako Huber, 2011: 122-124; figs 489-493, 764, 773-774 (ぷ゚).

\section{Diagnosis}

Distinguished from similar species (with ventral apophysis on palpal femur and with pointed processes on eye stalks: Pa. kapit sp. nov.; Pa. niah sp. nov.; Pa. pueh sp. nov.; Pa. sedgwicki; Pa. tahai comb. nov.) by shapes of procursus and appendix (procursus tip distinctively bifid, similar only in $P a$. niah sp. nov.). Females are difficult to distinguish from $P a$. niah sp. nov. and $P a$. pueh sp. nov. (internal transversal folds much more complex in Pa. bako than in Pa. niah sp. nov.; unknown in Pa. sedgwicki).

\section{New material examined}

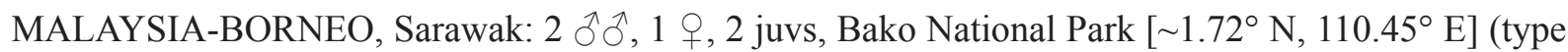
locality), rainforest on slope, 28 Mar. 1985 (C.L. \& P.R. Deeleman), RMNH.

\section{Distribution}

Known from type locality in Sarawak only (Fig. 1).

Panjange kapit Huber, sp. nov. urn:1sid:zoobank.org:act:07838D0A-C949-4316-8B22-6892CC371A3F

Figs 4, 10-14, 33-37, 42-51, 58-60

Panjange Bor 78: Huber \& Nuñeza 2015: 5, 43-44.

\section{Diagnosis}

Distinguished from similar species (with pair of straight pointed processes arising from near PME and ventral apophysis on male palpal femur: Pa. bako; Pa. niah sp. nov.; Pa. pueh sp. nov.; Pa. sedgwicki; $P a$. tahai comb. nov.) by longer palpal segments (especially femur and procursus; Figs 33-34), by shapes of procursus and appendix (Figs 33-34), and by longer epigynal scape (Figs 36-37; female of $P a$. sedgwicki unknown); from very similar $P a$. sedgwicki (male holotype examined) by distal structures of procursus, more slender male palpal tibia, and more distal ventral femur apophysis.

\section{Etymology}

Named for the type locality; noun in apposition.

\section{Type material}

MALAYSIA-BORNEO: holotype, §̊, Sarawak, near Kapit, forest along river (1.937-1.944 N, 112.904 $112.910^{\circ}$ E), 80-120 m a.s.1, 20 Jul. 2014 (B.A. Huber, S.B. Huber), ZFMK (Ar 14582).

\section{Other material examined}

MALAYSIA-BORNEO: Sarawak: $8 \hat{\jmath} \hat{\partial}, 6$ 우, 2 juvs, same data as holotype, ZFMK (Ar 14583-84;

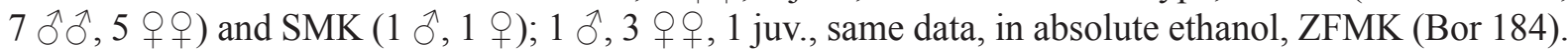



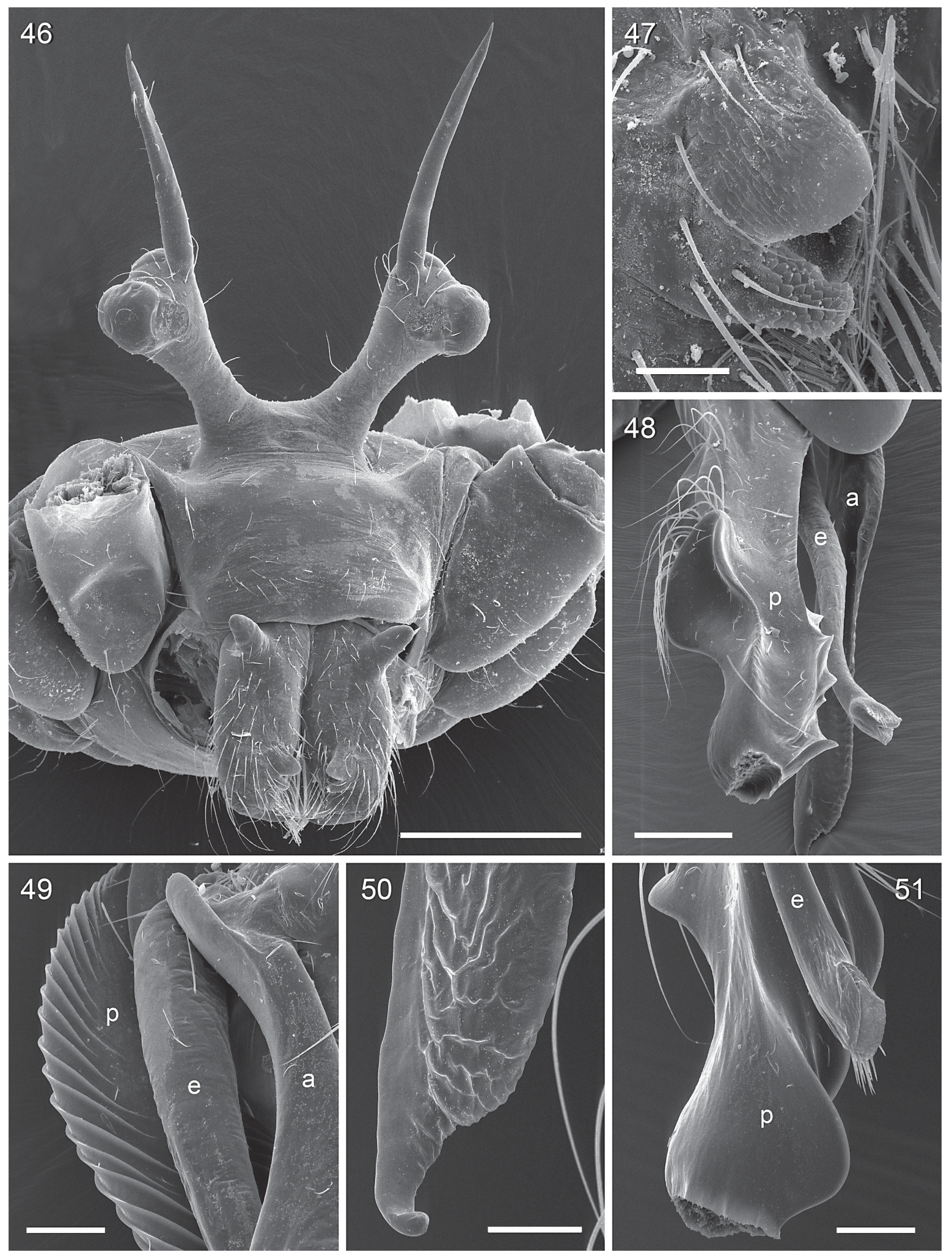

Figs 46-51. Panjange kapit Huber, sp. nov. (ZFMK Ar 14583). 46. Male prosoma, frontal view. 47. Right distal male cheliceral apophysis. 48. Right procursus (and bulbal processes), dorsal view. 49. Ridges on left procursus, prolateral view. 50. Tip of left appendix, prolateral view. 51. Tip of left procursus (and embolus), ventral view. Abbreviations: $\mathrm{a}=$ appendix; $\mathrm{e}=$ embolus; $\mathrm{p}=$ procursus. Scale lines: $30 \mu \mathrm{m}$ (47); $60 \mu \mathrm{m}$ (50); $100 \mu \mathrm{m}(49,51) ; 200 \mu \mathrm{m}$ (48); $400 \mu \mathrm{m}$ (46). 

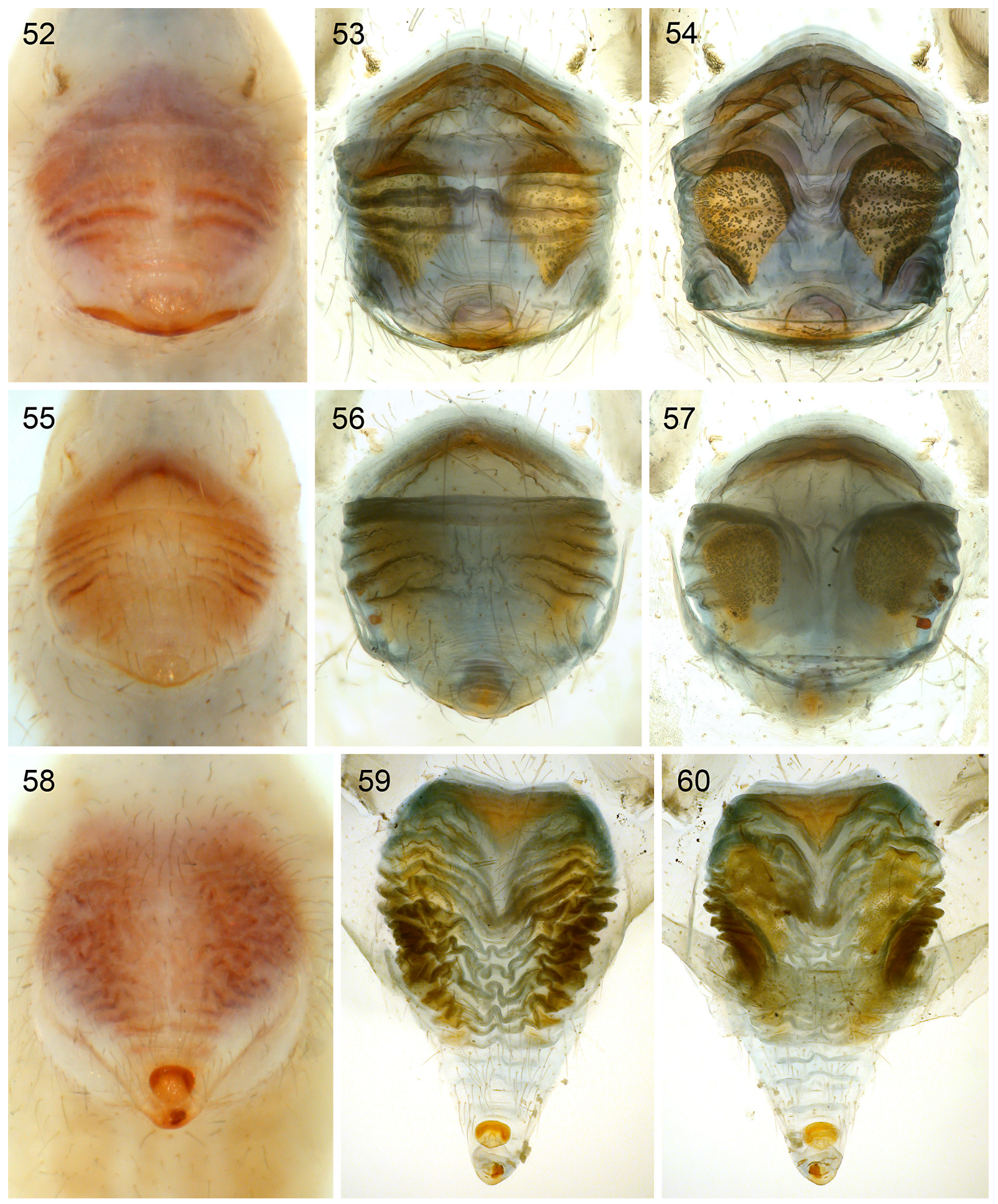

Figs 52-60. Female genitalia, untreated in ventral view, cleared in ventral and dorsal views. 5254. Panjange pueh Huber, sp. nov. (ZFMK Ar 14577). 55-57. Pa. niah Huber, sp. nov. (ZFMK Ar 14580). 58-60. Pa. kapit Huber, sp. nov. (ZFMK Ar 14584). 


\section{Description}

Male (holotype)

MeAsurements. Total body length 5.2, carapace width 1.2. Leg 1: $49.9(11.1+0.5+11.6+23.8+$ 2.9), tibia 2: 7.0, tibia 3: 4.1, tibia 4: 6.3; tibia $1 \mathrm{~L} / \mathrm{d}$ : 110. Distance PME-PME $520 \mu \mathrm{m}$, diameter PME $115 \mu \mathrm{m}$, distance PME-ALE $\sim 45 \mu \mathrm{m}$; AME absent.

Color. Carapace pale ochre yellow to whitish, posterior mark (Fig. 11) lost in ethanol, ocular area and clypeus dark brown (black in life), without black spots in AME area; sternum whitish; legs ochre-orange with dark brown patellae and tibia-metatarsus joints; abdomen ochre-gray, with black marks dorsally, monochromous ventrally.

Body. Habitus as in Figs 10-11; ocular area raised, each triad on long stalk, with pointed straight process arising from near PME (Fig. 4); carapace without median furrow; clypeus unmodified; sternum wider than long (0.75/0.55), unmodified. ALS as in Fig. 44.

Chelicerae. Similar to close relatives, with proximal pair of processes and with distinctively bifid distal apophyses (Figs 35, 46-47); without modified hairs; without stridulatory ridges.

PALPS. As in Figs 33-34; coxa unmodified; trochanter with slightly curved pointed retrolatero-ventral apophysis; femur with ventral apophysis; procursus very long, with row of about 18 ventral ridges (Fig. 49) and isolated patch of few prolateral ridges, with distinctive distal processes (Figs 48-49, 51), apparently without process in distal pit (Fig. 42); bulb with strong proximal sclerite, long slender appendix with hooked tip (Fig. 50), and long partly sclerotized embolus with short distal fringes (Fig. 51).

LEGS. Without spines and curved hairs; few vertical hairs; retrolateral trichobothrium on tibia 1 at $1.5 \%$; prolateral trichobothrium absent on tibia 1, present on other tibiae; tarsus 1 with $>40$ indistinct pseudosegments.

\section{Variation}

Tibia 1 in 8 other males: 10.6-11.9 (mean 11.3). Some males with black spots in AME area; abdominal marks variably distinct.

\section{Female}

In general similar to male but eye triads on low humps, much closer together (distance PME-PME $220 \mu \mathrm{m}$ ), without pointed processes. Tibia 1 in 6 females: 7.9-8.4 (mean 8.2). Epigynum weakly sclerotized plate with variably sclerotized posterior 'knob' on extensible scape (Figs 36, 58), internal anterior sclerite and complex transversal folds visible through cuticle; internal genitalia as in Figs 37, $59-60$.

\section{Natural history}

Webs were found among vegetation close to the ground, with the apex of the domed sheet connected to the underside of a leaf. Large numbers of Cecidomyiidae (deposited in ZFMK) were seen hanging from the silk lines in most webs. Egg sacs were slightly elongated, and contained about 25-30 eggs each $(\mathrm{n}=2)$.

\section{Distribution}

Known from type locality in Sarawak only (Fig. 1). 
Panjange tahai (Huber, 2011) comb. nov.

Pholcus tahai Huber, 2011: 158; figs 600-602, 616-617, 673-695 (ふ̊ํ).

\section{Diagnosis}

Easily distinguished from congeners by highly distinctive procursus (very long, with hinge between proximal and distal parts; fig. 674 in Huber 2011); females with distinctive internal genitalia (figs 617, 678 in Huber 2011) but difficult to distinguish externally from other representatives of the Pa. nigrifrons group.

\section{New material examined}

INDONESIA-BORNEO, Central Kalimantan: 1 \%, Tumbang Tahai $\left(2^{\circ} 02^{\prime} \mathrm{S}, 113^{\circ} 35^{\prime} \mathrm{E}\right)$ [type locality],

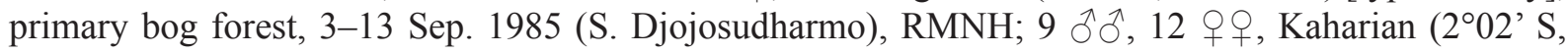
$113^{\circ} 40^{\prime}$ E), marshy primary forest, foliage, 2-16 Sep. 1985 (S. Djojosudharmo), RMNH; 1 $^{\top}, 4$ 우, same data but bog forest, RMNH; $5 \overbrace{}^{\lambda} \partial^{\lambda}, 5$ 우 (2 vials), $40 \mathrm{~km} \mathrm{NW}$ Palangkaraya [ $1.95^{\circ} \mathrm{S}, 113.75^{\circ} \mathrm{E}]$, secondary forest, leaves, Sep. 1985 (S. Djojosudharmo), RMNH.

\section{Distribution}

Known from three localities in Central Kalimantan (Fig. 1).

\section{Panjange iban Huber, 2011}

Figs 61-62

Panjange iban Huber, 2011: 119-121; figs 469-488, 770-772, 791-792 (ð̊ㅇ).

\section{Diagnosis}

Distinguished from similar species (with ventral apophysis on palpal femur, without pointed processes on eye stalks: $P a$. kubah sp. nov.; Pa. nigrifrons; $P a$. seowi sp. nov.) by distinctive ventral process of procursus (near distal end of ridges; fig. 470 in Huber 2011); females are difficult to distinguish externally from congeners in Sarawak (distinctive internal folds arranged in anterior semicircular pattern; large pore plates); from $P a$. nigrifrons by very short scape.

\section{New material examined}

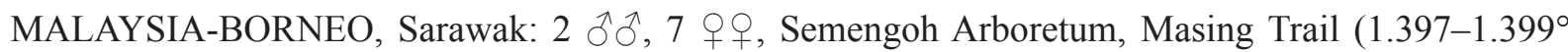
$\mathrm{N}, 110.317-110.322^{\circ}$ E), 60-80 m a.s.1., 17 July 2014 (B.A. Huber), ZFMK (Ar 14585); 2 우, 2 juvs, same data, in absolute ethanol, ZFMK (Bor 227); $6 \hat{\jmath} \hat{\jmath}, 3$ q 9 , same locality, Apr. 1985 (C.L. \& P.R. Deeleman), RMNH.

\section{Natural history}

The webs had a diameter of about $10-20 \mathrm{~cm}$ and were found among vegetation in primary forest close to the ground where the domed sheets were attached to the undersides of leaves.

\section{Distribution}

Known from type locality in Sarawak only (Fig. 1).

Panjange nigrifrons Deeleman-Reinhold \& Deeleman, 1983 Figs 5, 86-88

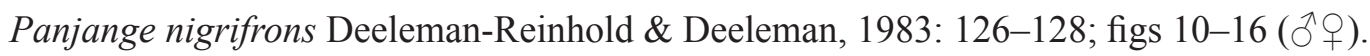




\section{Diagnosis}

Distinguished from similar species (with ventral apophysis on palpal femur, without pointed processes on eye stalks: $P a$. iban; $P a$. kubah sp. nov.; Pa. seowi sp. nov.) by low number of ridges ventrally on procursus (only three; fig. 13 in Deeleman-Reinhold \& Deeleman 1983); by short male palpal trochanter apophysis (fig. 15 in Deeleman-Reinhold \& Deeleman 1983), and by distinctive female genitalia (Figs 86-88; internal lateral structures visible through cuticle; long scape).

\section{New material examined}

INDONESIA-BORNEO, East Kalimantan: 2 え $\partial^{\lambda}, 2$ 우, Sepaku [ $\left.0.91^{\circ} \mathrm{S}, 116.77^{\circ} \mathrm{E}\right], 40 \mathrm{~km} \mathrm{~N}$ of Balikpapan (type locality), primary forest, 20-21 Jul. 1982 (collector unknown), RMNH.
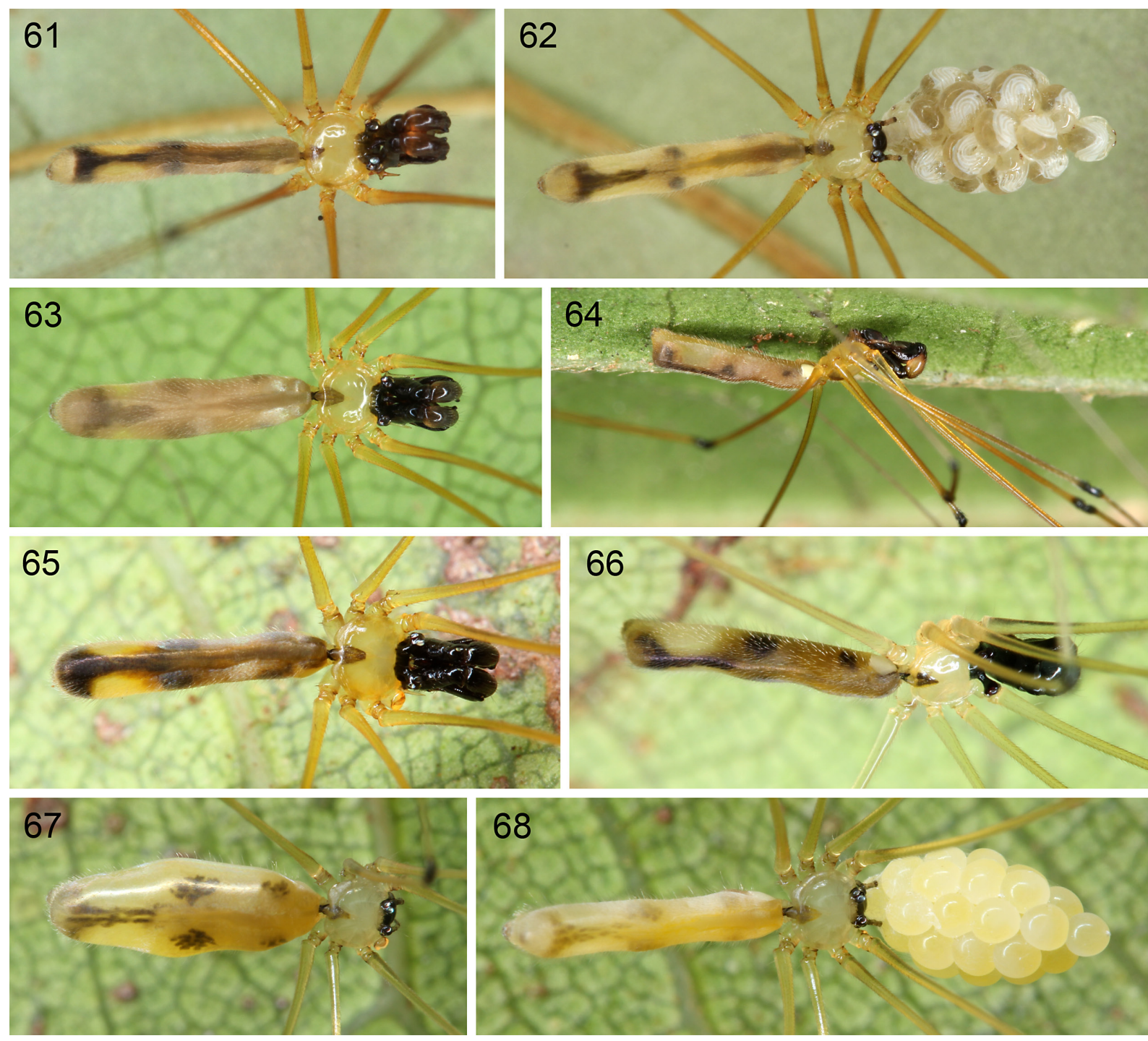

Figs 61-68. Live specimens. 61-62. $P a$. iban Huber, 2011, $\delta$ and $q$ with egg-sac from Semengoh.

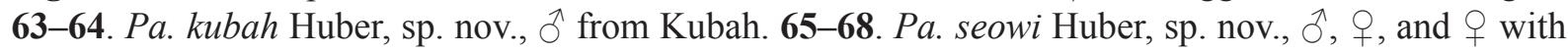
egg-sac from Penrissen. 


\section{Description - amendments}

Male distal cheliceral apophyses clearly bipartite as in other species described herein (this was correctly noted in the original description but not correctly drawn in fig. 11). Appendix with very distinct and unique pocket at $\sim 60 \%$ of its length. Tibia $1 \mathrm{~L} / \mathrm{d}$ : 100; tibia 2/tibia 4 length: 1.09 (not 1.33 as in original description); distance PME-PME: $420 \mu \mathrm{m}$; retrolateral trichobothrium at $2 \%$.

\section{Distribution}

Known from two localities in Kalimantan only (Deeleman-Reinhold \& Deeleman 1983; Fig. 1).

Panjange kubah Huber, sp. nov.

urn:1sid:zoobank.org:act:CF978A33-4706-4705-8245-86776DB7E34C

Figs 6, 63-64, 69-81, 89-91

Panjange Bor 109: Huber \& Nuñeza 2015: 5, 43-44.

\section{Diagnosis}

Easily distinguished from most congeners by distinctive transversal sclerite on procursus (Fig. 70); from very similar $P a$. seowi sp. nov. by other details of procursus (unique prolateral process, Figs 69, 77-78; distal element longer, Fig. 70; absence of prolateral ridges on procursus, Fig. 69). Females are easily distinguished from $\mathrm{Pa}$. nigrifrons by short scape but difficult to distinguish externally from other congeners in Sarawak (distinctive shape of pore plates and pair of median sclerites; similar only in $\mathrm{Pa}$. seowi sp. nov.).

\section{Etymology}

Named for the type locality; noun in apposition.

\section{Type material}

MALAYSIA-BORNEO: holotype, $\hat{\jmath}$, Sarawak, Kubah National Park, along Waterfall Trail (1.596$1.606^{\circ} \mathrm{N}, 110.180-110.187^{\circ}$ E), 200-300 m a.s.1., 12 Jul. 2014 (B.A. Huber, S.B. Huber), ZFMK (Ar 14586).

\section{Other material examined}

MALAYSIA-BORNEO, Sarawak: $2 \hat{\jmath}, 7$ $q$, , same data as holotype, ZFMK (Ar 14587-88); 2 우, 2 juvs, same data, in absolute ethanol, ZFMK (Bor 189).

\section{Description}

Male (holotype)

MeAsurements. Total body length 4.5, carapace width 1.2. Leg 1: $42.0(9.3+0.5+9.6+20.1+2.5)$, tibia 2: 6.1, tibia 3: 3.6, tibia 4: 5.6; tibia 1 L/d: 99. Distance PME-PME $445 \mu \mathrm{m}$, diameter PME $105 \mu \mathrm{m}$, distance PME-ALE $\sim 5 \mu \mathrm{m}$; AME absent.

CoLor. Carapace pale ochre yellow to whitish, posterior mark (Fig. 63) lost in ethanol, ocular area and clypeus dark brown (black in life), without black marks in AME area; sternum whitish; legs ochreorange with dark brown patellae and tibia-metatarsus joints; abdomen ochre-gray, with black marks dorsally, monochromous ventrally.

BoDy. Habitus as in Figs 63-64; ocular area raised, each triad on medium long stalk, without pointed process (cf. Fig. 6); carapace without median furrow; clypeus unmodified; sternum wider than long $(0.75 / 0.60)$, unmodified. 


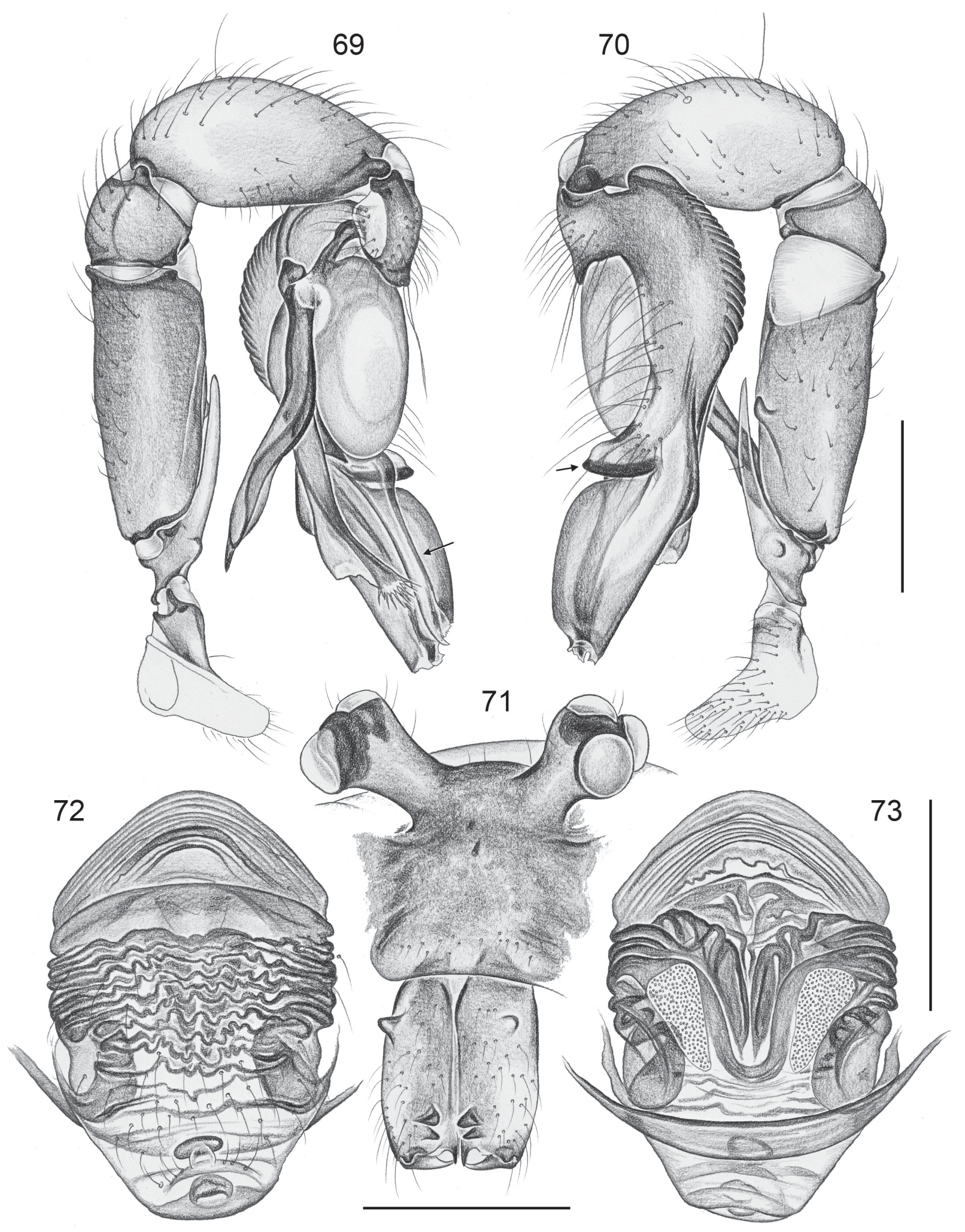

Figs 69-73. Panjange kubah Huber, sp. nov. (ZFMK Ar 14587-88). 69-70. Left male palp, prolateral and retrolateral views (arrows point at distinctive processes). 71. Male ocular area, clypeus, and chelicerae, oblique frontal view. 72-73. Cleared female genitalia, ventral and dorsal views. Scale lines: $0.5 \mathrm{~mm}$. 

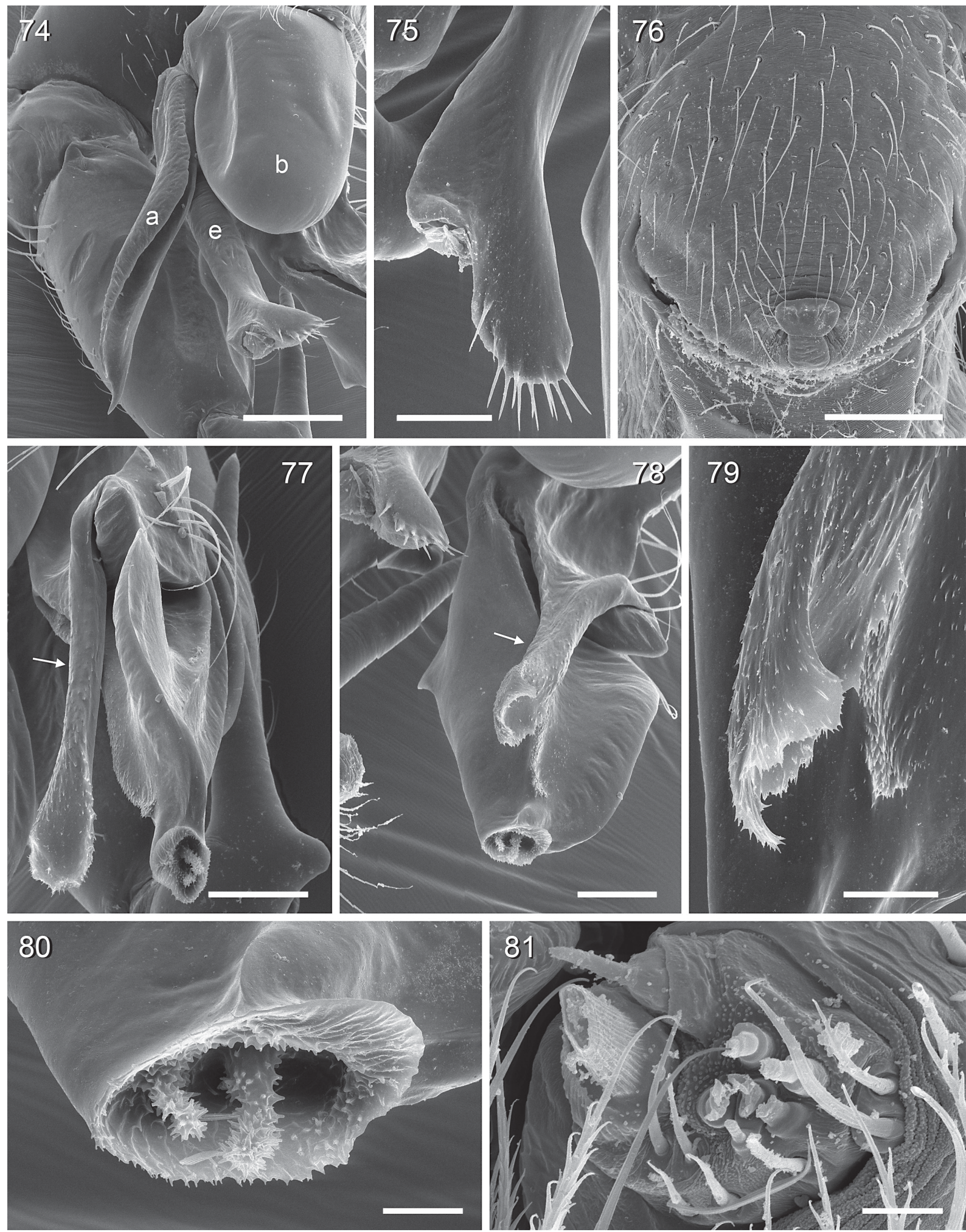

Figs 74-81. Panjange kubah Huber, sp. nov. (ZFMK Ar 14587-88). 74. Left bulb, prolateral (slightly distal) view. 75. Tip of left embolus. 76. Epigynum, ventral view. 77-78. Left procursus, dorso-distal and prolateral views (arrows point at distinctive membranous process). 79. Membranous process of left procursus. 80. Tip of left procursus, distal view. 81. Female ALS. Abbreviations: a = appendix; $\mathrm{b}=$ genital bulb; $\mathrm{e}=$ embolus. Scale lines: $10 \mu \mathrm{m}(81) ; 20 \mu \mathrm{m}(80) ; 40 \mu \mathrm{m}(79) ; 80 \mu \mathrm{m}(75) ; 100 \mu \mathrm{m}$ (77-78); $200 \mu \mathrm{m}(74,76)$. 
CHELICERAe. Similar to close relatives, with proximal pair of processes and distinctively bipartite distal apophyses (Fig. 71); without modified hairs; without stridulatory ridges.

Palps. As in Figs 69-70; coxa unmodified; trochanter with slightly curved pointed retrolatero-ventral apophysis; femur with curved finger-shaped ventral apophysis; procursus with row of about 17 ventral ridges, with distinctive transversal sclerite and long prolateral process close to large flat distal element (Figs 77-78), with two distinct spiny processes in distal pit (Fig. 80); bulb with strong proximal sclerite, slightly curved appendix, and long partly sclerotized embolus with distinct distal fringes (Figs 74-75).

LEGS. Without spines and curved hairs; few vertical hairs; retrolateral trichobothrium on tibia 1 at $2 \%$; prolateral trichobothrium absent on tibia 1, present on other tibiae; tarsus 1 with many pseudosegments but only $\sim 10$ distally visible in dissecting microscope.

\section{Variation}

Tibia 1 in 2 other males: 9.1, 9.3. One male with irregular black marks in AME area (Fig. 6).

Female

In general similar to male but eye triads on low humps, much closer together (distance PME-PME $230 \mu \mathrm{m}$ ). Tibia 1 in 6 females: 6.9-7.9 (mean 7.4). Epigynum weakly sclerotized plate with variably large and variably sclerotized posterior 'knob' (Figs 72, 76, 89), internal arch and complex transversal folds visible through cuticle; internal genitalia as in Figs 73, 90-91.

\section{Natural history}

Most specimens were found in a very limited area close to a waterfall. The domed webs had a diameter of about 15-20 cm and in each case the apex of the dome was attached to the underside of a leaf where the spider rested.

\section{Distribution}

Known from type locality in Sarawak only (Fig. 1).

Panjange seowi Huber, sp. nov. urn:Isid:zoobank.org:act:96424104-A78F-41D3-AA64-65DA79138D21

Figs 7, 65-68, 82-85, 92-94

Panjange Bor 100: Huber \& Nuñeza 2015: 5, 43-44.

\section{Diagnosis}

Easily distinguished from most congeners by distinctive transversal sclerite on procursus (Fig. 83); from the very similar $P a$. kubah sp. nov. by other details of procursus (prolateral ridges on procursus, Fig. 82; small transparent process close to transversal sclerite, Fig. 82; absence of long membranous prolateral process; distal element shorter). Females are easily distinguished from Pa. nigrifrons by short scape but difficult to distinguish externally from other congeners in Sarawak (distinctive shape of pore plates and pair of median sclerites; similar only in Pa. kubah sp. nov.).

\section{Etymology}

Named for Francis Seow-Choen from Singapore, surgeon and expert on stick insects. 

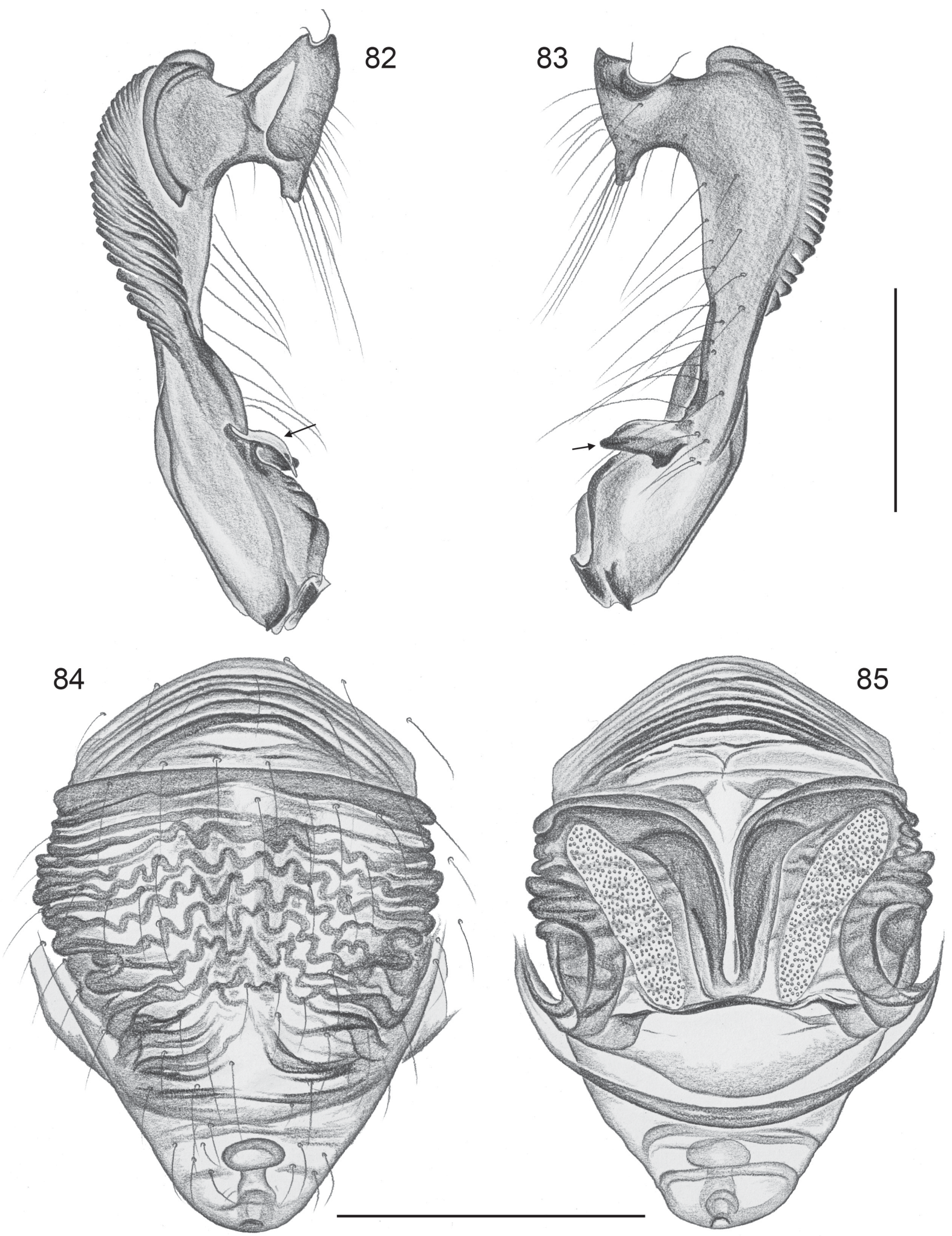

Figs 82-85. Panjange seowi Huber, sp. nov. (ZFMK Ar 14590-91). 82-83. Left procursus, prolateral and retrolateral views (arrows point at distinctive processes). 84-85. Cleared female genitalia, ventral and dorsal views. Scale lines: $0.5 \mathrm{~mm}$. 


\section{Type material}

MALAYSIA-BORNEO: holotype, ${ }^{\AA}$, Sarawak, Mt. Penrissen near Borneo Highland Resort, Ma Gaseng Trail (1.124-1.127 $\mathrm{N}, 110.217^{\circ}$ E), 870-930 m a.s.1., 14 Jul. 2014 (B.A. Huber, S.B. Huber), ZFMK (Ar 14589).

\section{Other material examined}

MALAYSIA-BORNEO, Sarawak: 1 $\precsim, 4$ 우, 1 juv., same data as holotype, ZFMK (Ar 14590-91); 3 우, 1 juv., same data, in absolute ethanol, ZFMK (Bor 217).

\section{Description}

Male (holotype)

MeAsurements. Total body length 4.3, carapace width 1.1. Leg 1: $46.3(10.4+0.5+10.5+22.1+2.8)$, tibia 2: 6.5, tibia 3: 3.7, tibia 4: 5.7; tibia $1 \mathrm{~L} / \mathrm{d}$ : 114. Distance PME-PME $375 \mu \mathrm{m}$, diameter PME 105 $\mu \mathrm{m}$, distance PME-ALE $45 \mu \mathrm{m}$; AME absent.

Color. Carapace pale ochre yellow to whitish, posterior mark (Fig. 65) lost in ethanol, ocular area and clypeus dark brown (black in life), with pair of black marks in AME area; sternum whitish; legs ochreorange with dark brown patellae and tibia-metatarsus joints; abdomen ochre-gray, with black marks dorsally, monochromous ventrally.

BoDy. Habitus as in Figs 65-66; ocular area raised, each triad on medium long stalk, without pointed process (Fig. 7); carapace without median furrow; clypeus unmodified; sternum wider than long $(0.70 / 0.60)$, unmodified.

Chelicerae. Similar to close relatives, with proximal pair of processes and distinctively bipartite distal apophyses (cf. Fig. 71); without modified hairs; without stridulatory ridges.

PALPS. In general very similar to Pa. kubah sp. nov. (cf. Figs 69-70), but trochanter apophysis slightly shorter and distally thinner/more pointed; procursus with distinctive prolateral ridges (Fig. 82), with small transparent process close to transversal sclerite (Fig. 82), without long membranous prolateral process, entire distal element shorter (Fig. 83); bulbal processes apparently not distinguishable from those in Pa. kubah sp. nov.

LEGs. Without spines and curved hairs; few vertical hairs; retrolateral trichobothrium on tibia 1 at 2\%; prolateral trichobothrium absent on tibia 1 , present on other tibiae; tarsus $1>40$ pseudosegments, proximally very indistinct.

\section{Variation}

Tibia 1 in other male: 10.3; other male paler and transversal sclerite of procursus without proximal process.

\section{Female}

In general similar to male but eye triads on low humps, much closer together (distance PME-PME $230 \mu \mathrm{m})$. Tibia 1 in 3 females: 7.8, 8.4, 8.8. Epigynum weakly sclerotized plate with large weakly sclerotized posterior 'knob' (Figs 84, 92), internal arch and transversal folds visible through cuticle; internal genitalia as in Figs 85, 93-94. 

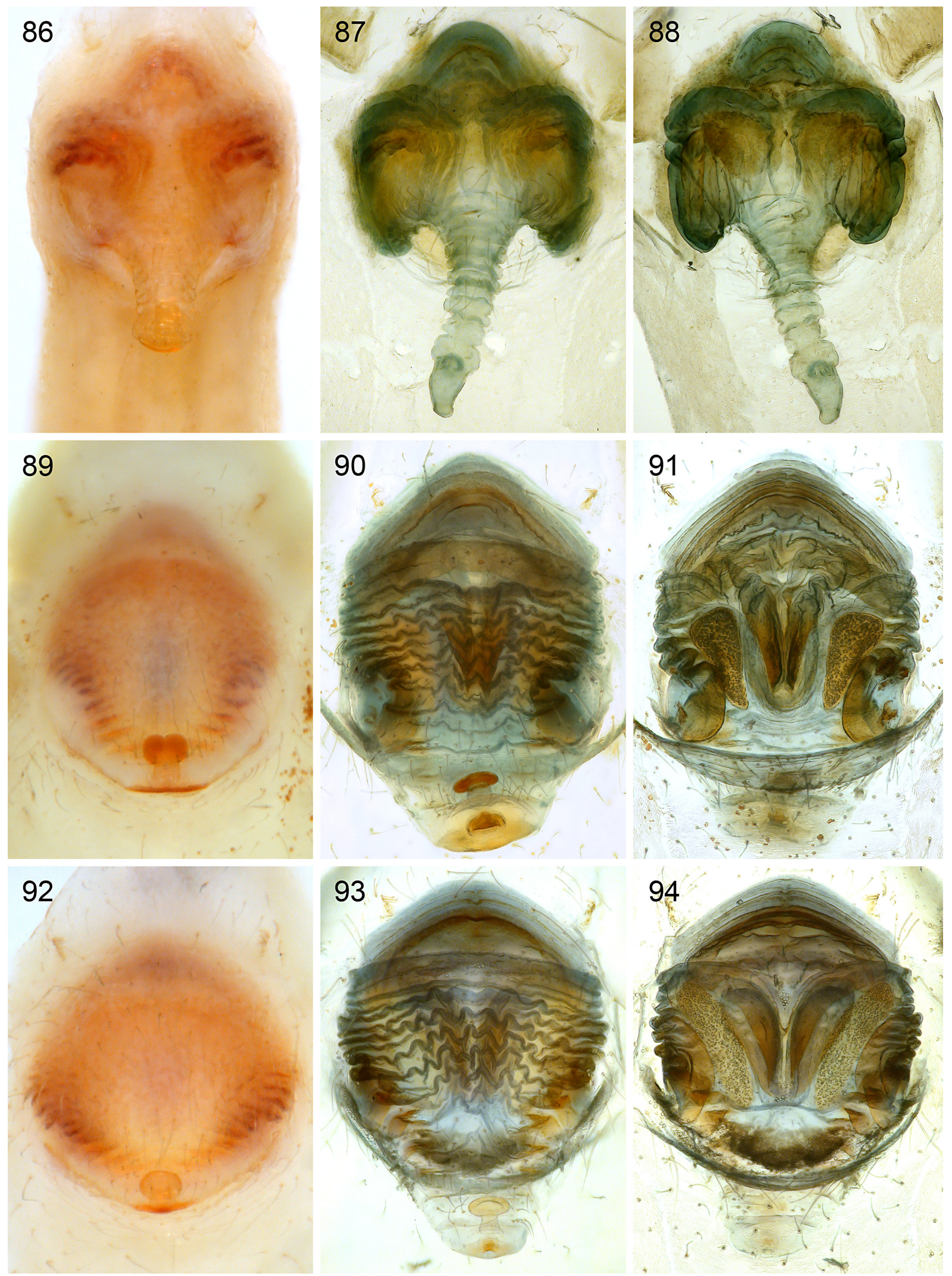

Figs 86-94. Female genitalia, untreated in ventral view, cleared in ventral and dorsal views. 8688. Panjange nigrifrons Deeleman-Reinhold \& Deeleman, 1983 (RMNH, Sepaku). 89-91. Pa. kubah Huber, sp. nov. (ZFMK Ar 14588). 92-94. Pa. seowi Huber, sp. nov. (ZFMK Ar 14591). 


\section{Natural history}

The domed webs were found under green leaves among vegetation, usually about $0.5 \mathrm{~m}$ above the ground.

\section{Distribution}

Known from type locality in Sarawak only (Fig. 1).

\section{Discussion}

We document high levels of diversity and endemism of Panjange in western Sarawak, but it remains unclear to which extent this can be extrapolated to other, mostly very poorly sampled regions of Borneo. Panjange does occur in Kalimantan, but it might be significantly less diverse there than in western Sarawak. A large part of Kalimantan is (or was originally) covered by peat swamp forest that in general is thought to have distinctive but limited diversity (e.g., Mohamedsaid \& Holloway 1999; Posa et al. 2011). However, at least northern West Kalimantan is expected to have similar high diversity and endemism as western Sarawak, but this region seems to be among the most poorly explored regions worldwide, as far as spiders are concerned.

An extrapolation from Sarawak to unexplored regions in Borneo is particularly problematic in light of our surprising finding that Panjange seems to be absent from Sabah. Absence is of course difficult to document but the available data strongly suggest a real pattern rather than an artifact of sampling. First, we sampled with the same methodology and diligence at six localities west of Niah (sea level to $930 \mathrm{~m}$ a.s.1.) as we did at nine localities east of Niah (sea level to $1650 \mathrm{~m}$ a.s.1.). Panjange was found at all six

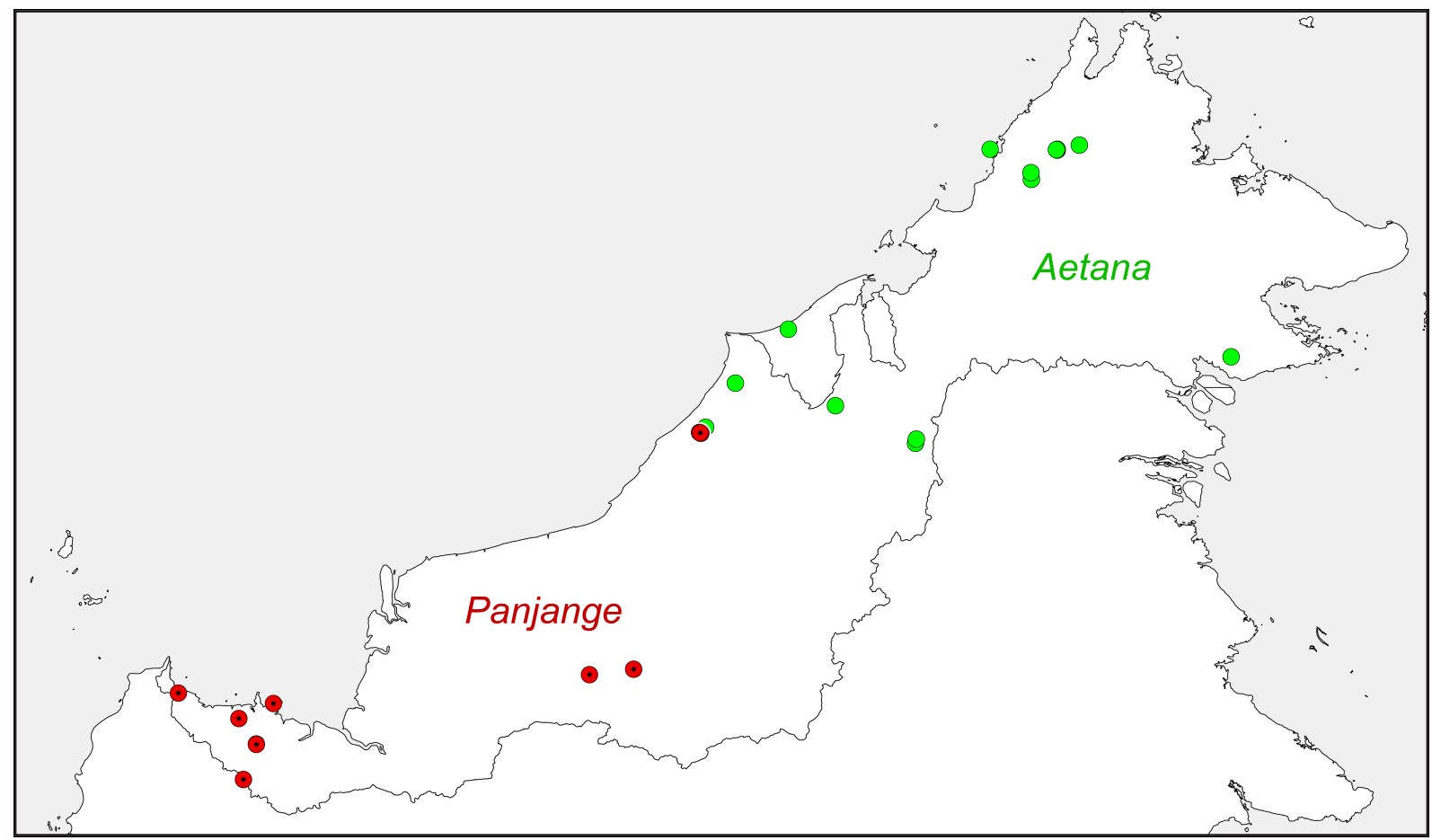

Fig. 95. Known distributions of the genera Panjange Deeleman-Reinhold \& Deeleman, 1983 and Aetana Huber, 2005 in northern Borneo, showing the distinctness of western and eastern regions (distribution of Aetana from Huber et al. 2015). 
localities west of Niah (and in Niah), but in none of the nine localities east of Niah. Second, the same pattern is apparent in the large collections made by C. Deeleman-Reinhold since the 1980s in Sarawak (Bako, Semengoh) and Sabah (Mt. Kinabalu, Poring, Sepilok) (Pholcidae mostly published in Huber 2011). Third, extensive more recent quantitative sampling by A. Floren in Sabah (Crocker Range, Mt. Kinabalu, Tawau) also did not produce a single specimen of Panjange (Huber 2011 and B.A. Huber, unpubl. data).

Further evidence suggesting a real pattern comes from another pholcid genus, Aetana Huber, 2005. This genus is not particularly close to Panjange (same subfamily but not part of the Pholcus group of genera like Panjange; Huber 2011) but is relevant in this context because it shows the exactly opposite distribution in northern Borneo. We found various species of Aetana at eight of nine localities east of Niah (and in Niah), but in none of the six localities west of Niah (Huber et al. 2015). Figure 95 summarizes current knowledge about the distributions of Panjange and Aetana in northern Borneo, combining all known records. Obviously, large sampling gaps remain, and a meaningful interpretation will have to build on a much more intense sampling including Kalimantan. However, data on better studied organisms such as birds have also supported a biogeographical divide between Sabah and Sarawak despite continuous rainforest (Gawin et al. 2014; Sheldon et al. 2015). These authors mainly suggest historical reasons for this pattern, such as early Pleistocene rainforest refugia in Sabah versus dry habitats in Sarawak (at that time part of central Sundaland). Whether the same explanations apply to spiders as to birds remains to be established.

\section{Acknowledgements}

We thank the Sarawak Museum Department for assistance in field logistics and Samuel B. Huber for help in the field. The Natural History Museum in Kuching kindly offered its facilities as the base of the field work. Permits were received from the Forest Department, Sarawak (Permit No. NCCD.907.4.4(JLD.10)-211, Park Permit No. 174/2014). We thank two anonymous reviewers for commenting on a previous version of the manuscript. The German Research Foundation provided financial support (DFG Project HU 980/11-1).

\section{References}

Brown B.V. 1993. A further chemical alternative to critical-point-drying for preparing small (or large) flies. Fly Times 11: 10.

Deeleman-Reinhold C.L. 1986a. Leaf-dwelling Pholcidae in Indo-Australian rain forests. In: Eberhard W.C., Lubin Y.D. \& Robinson B.C. (eds) Proceedings of the Ninth International Congress of Arachnology, Panama 1983: 45-48. Smithsonian Institution Press, Washington.

Deeleman-Reinhold C.L. 1986b. Studies on tropical Pholcidae II. Redescription of Micromerys gracilis Bradley and Calapnita vermiformis Simon (Araneae, Pholcidae) and description of some related new species. Memoirs of the Queensland Museum 22 (2): 205-224.

Deeleman-Reinhold C.L. \& Deeleman P.R. 1983. Studies on tropical Pholcidae I. Panjange, a new genus of Indo-Australian leaf- and rock-dwelling pholcid spiders (Araneae). Zoologische Mededelingen 57 (14): 121-130.

Deeleman-Reinhold C.L. \& Platnick N.I. 1986. A new Panjange from northern Borneo (Araneae, Pholcidae). Journal of the New York Entomological Society 94 (4): 559-561.

Dimitrov D., Astrin J.J. \& Huber B.A. 2013. Pholcid spider molecular systematics revisited, with new insights into the biogeography and the evolution of the group. Cladistics 29: 132-146. http://dx.doi. org/10.1111/j.1096-0031.2012.00419.x 
HUBER B.A. \& LEH MOI UNG C., Panjange nigrifrons group in Borneo

Gawin D.F., Rahman M.A., Ramji M.F.S., Smith B.T., Lim H.C., Moyle R.G. \& Sheldon F.H. 2014. Patterns of avian diversification in Borneo: the case of the endemic Mountain Black-eye (Chlorocharis emiliae). The Auk: Advances in Ornithology 131: 86-99. http://dx.doi.org/10.1642/AUK-13-190.1

Huber B.A. 2000. New World pholcid spiders (Araneae: Pholcidae): a revision at generic level. Bulletin of the American Museum of Natural History 254: 1-348. http://dx.doi.org/10.1206/00030090(2000)254<0001:NWPSAP $>2.0$.CO;2

Huber B.A. 2001. The pholcids of Australia (Araneae; Pholcidae): taxonomy, biogeography, and relationships. Bulletin of the American Museum of Natural History 260: 1-144. http://dx.doi. org/10.1206/0003-0090(2001)260\%3C0001:TPOAAP\%3E2.0.CO;2

Huber B.A. 2005. High species diversity, male-female coevolution, and metaphyly in Southeast Asian pholcid spiders: the case of Belisana Thorell, 1898 (Araneae, Pholcidae). Zoologica 155: 1-126.

Huber B.A. 2009. Life on leaves: leaf-dwelling pholcids of Guinea, with emphasis on Crossopriza cylindrogaster, a spider with inverted resting position, pseudo-eyes, lampshade web, and tetrahedral egg-sac (Araneae: Pholcidae). Journal of Natural History 43: 2491-2523. http://dx.doi. org/10.1080/00222930903207876

Huber B.A. 2011. Revision and cladistic analysis of Pholcus and closely related taxa (Araneae, Pholcidae). Bonner zoologische Monographien 58: 1-509.

Huber B.A. 2012. Revision and cladistic analysis of the Afrotropical endemic genus Smeringopus Simon, 1890 (Araneae: Pholcidae). Zootaxa 3461: 1-138.

Huber B.A. 2013. Revision and cladistic analysis of the Guineo-Congolian spider genus Smeringopina Kraus (Araneae, Pholcidae). Zootaxa 3713: 1-160. http://dx.doi.org/10.11646/zootaxa.3713.1.1

Huber B.A., Fischer N. \& Astrin J.J. 2010. High level of endemism in Haiti's last remaining forests: a revision of Modisimus (Araneae: Pholcidae) on Hispaniola, using morphology and molecules. Zoological Journal of the Linnean Society 158: 244-299. http://dx.doi.org/10.1111/j.1096-3642.2009.00559.x

Huber B.A. \& Fleckenstein N. 2008. Comb-hairs on the fourth tarsi in pholcid spiders (Araneae, Pholcidae). Journal of Arachnology 36: 232-240. http://dx.doi.org/10.1636/CSh07-71.1

Huber B.A. \& Nuñeza O.M. 2015. Evolution of genital asymmetry, exaggerated eye stalks, and extreme palpal elongation in Panjange spiders (Araneae: Pholcidae). European Journal of Taxonomy 169: 1-46. http://dx.doi.org/10.5852/ejt.2015.169

Huber B.A., Nuñeza O.M. \& Leh Moi Ung C. 2015. Revision, phylogeny, and microhabitat shifts in the Southeast Asian spider genus Aetana (Araneae, Pholcidae). European Journal of Taxonomy 162: 1-78. http://dx.doi.org/10.5852/ejt.2015.162

Huber B.A., Pérez-González A., Astrin J.J., Blume C. \& Baptista R. 2013. Litoporus iguassuensis Mello-Leitão, 1918 (Araneae, Pholcidae): camouflaged retreat, sexual dimorphism, female color polymorphism, intra-specific genital variation, and description of the male. Zoologischer Anzeiger 252: 511-521. http://dx.doi.org/10.1016/j.jcz.2012.12.001

Huber B.A. \& Schütte A. 2009. Preliminary notes on leaf-dwelling Metagonia spiders (Araneae: Pholcidae) in the Esquinas Rainforest near La Gamba, Costa Rica: leaf preference, mimesis, and web structure. Contributions to Natural History (Bern) 12: 681-697.

Mohamedsaid M.S. \& Holloway J.D. 1999. Biogeography of the Bornean Galerucinae (Coleoptera: Chrysomelidae). Serangga 4 (2): 151-173.

Posa M.R.C., Wijedasa L.S. \& Corlett R.T. 2011. Biodiversity and conservation of tropical peat swamp forests. BioScience 61 (1): 49-57. http://dx.doi.org/10.1525/bio.2011.61.1.10 
Sheldon F.H., Lim H.C. \& Moyle R.G. 2015. Return to the Malay Archipelago: the biogeography of Sundaic rainforest birds. Journal of Ornithology 156 (supplement 1): 91-113. http://dx.doi.org/10.1007/ $\underline{\text { s10336-015-1188-3 }}$

Manuscript received: 5 October 2015

Manuscript accepted: 9 December 2015

Published on: 24 March 2016

Topic editor: Rudy Jocqué

Desk editor: Kristiaan Hoedemakers

Printed versions of all papers are also deposited in the libraries of the institutes that are members of the EJT consortium: Muséum national d'Histoire naturelle, Paris, France; Botanic Garden Meise, Belgium; Royal Museum for Central Africa, Tervuren, Belgium; Natural History Museum, London, United Kingdom; Royal Belgian Institute of Natural Sciences, Brussels, Belgium; Natural History Museum of Denmark, Copenhagen, Denmark. 